\title{
Challenges and opportunities in land surface modelling of savanna ecosystems
}

\author{
Rhys Whitley $^{1}$, Jason Beringer ${ }^{2}$, Lindsay B. Hutley ${ }^{3}$, Gabriel Abramowitz ${ }^{4}$, Martin G. De Kauwe ${ }^{1}$, Bradley Evans ${ }^{5}$, \\ Vanessa Haverd $^{6}$, Longhui Li ${ }^{7}$, Caitlin Moore ${ }^{8}$, Youngryel Ryu ${ }^{9}$, Simon Scheiter ${ }^{10}$, Stanislaus J. Schymanski ${ }^{11}$, \\ Benjamin Smith $^{12}$, Ying-Ping Wang ${ }^{13}$, Mathew Williams ${ }^{14}$, and Qiang Yu ${ }^{7}$ \\ ${ }^{1}$ Department of Biological Sciences, Macquarie University, North Ryde, NSW 2109, Australia \\ ${ }^{2}$ School of Agriculture and Environment, University of Western Australia, Crawley, WA 6009, Australia \\ ${ }^{3}$ Research Institute for the Environment and Livelihoods, Charles Darwin University, Casuarina, NT 0909, Australia \\ ${ }^{4}$ Climate Change Research Centre, University of New South Wales, Kensington, NSW 2033, Australia \\ ${ }^{5}$ Faculty of Agriculture and Environment, University of Sydney, Eveleigh, NSW 2015, Australia \\ ${ }^{6}$ CSIRO Ocean and Atmosphere, Canberra 2601, Australia \\ ${ }^{7}$ School of Life Sciences, University of Technology Sydney, Ultimo, NSW 2007, Australia \\ ${ }^{8}$ School of Earth, Atmosphere and Environment, Monash University, VIC 3800, Clayton, Australia \\ ${ }^{9}$ Department of Landscape Architecture and Rural Systems Engineering, Seoul National University, Seoul, South Korea \\ ${ }^{10}$ Biodiversität und Klima Forschungszentrum, Senckenberg Gesellschaft für Naturforschung, Senckenberganlage 25, \\ 60325 Frankfurt am Main, Germany \\ ${ }^{11}$ ETH Zurich, Department of Environmental System Science, Zurich, Switzerland \\ ${ }^{12}$ Department of Physical Geography and Ecosystem Science, Lund University, Lund, Sweden \\ ${ }^{13}$ CSIRO Ocean and Atmosphere, Aspendale, Victoria 3195, Australia \\ ${ }^{14}$ School of GeoSciences, University of Edinburgh, Edinburgh, UK
}

Correspondence to: Jason Beringer (jason.beringer@uwa.edu.au)

Received: 6 May 2016 - Discussion started: 11 May 2016

Revised: 6 August 2017 - Accepted: 28 August 2017 - Published: 24 October 2017

\begin{abstract}
The savanna complex is a highly diverse global biome that occurs within the seasonally dry tropical to subtropical equatorial latitudes and are structurally and functionally distinct from grasslands and forests. Savannas are open-canopy environments that encompass a broad demographic continuum, often characterised by a changing dominance between $\mathrm{C}_{3}$-tree and $\mathrm{C}_{4}$-grass vegetation, where frequent environmental disturbances such as fire modulates the balance between ephemeral and perennial life forms. Climate change is projected to result in significant changes to the savanna floristic structure, with increases to woody biomass expected through $\mathrm{CO}_{2}$ fertilisation in mesic savannas and increased tree mortality expected through increased rainfall interannual variability in xeric savannas. The complex interaction between vegetation and climate that occurs in savannas has traditionally challenged terrestrial biosphere models (TBMs), which aim to simulate the interaction between the
\end{abstract}

atmosphere and the land surface to predict responses of vegetation to changing in environmental forcing. In this review, we examine whether TBMs are able to adequately represent savanna fluxes and what implications potential deficiencies may have for climate change projection scenarios that rely on these models. We start by highlighting the defining characteristic traits and behaviours of savannas, how these differ across continents and how this information is (or is not) represented in the structural framework of many TBMs. We highlight three dynamic processes that we believe directly affect the water use and productivity of the savanna system: phenology, root-water access and fire dynamics. Following this, we discuss how these processes are represented in many current-generation TBMs and whether they are suitable for simulating savanna fluxes.

Finally, we give an overview of how eddy-covariance observations in combination with other data sources can be used 
in model benchmarking and intercomparison frameworks to diagnose the performance of TBMs in this environment and formulate road maps for future development. Our investigation reveals that many TBMs systematically misrepresent phenology, the effects of fire and root-water access (if they are considered at all) and that these should be critical areas for future development. Furthermore, such processes must not be static (i.e. prescribed behaviour) but be capable of responding to the changing environmental conditions in order to emulate the dynamic behaviour of savannas. Without such developments, however, TBMs will have limited predictive capability in making the critical projections needed to understand how savannas will respond to future global change.

\section{Introduction}

Savanna ecosystems are a diverse and complex biome covering approximately 15 to $20 \%$ of the global terrestrial surface (Scholes and Hall, 1996) and are important in providing ecosystem services that maintain biodiversity and support the majority of the global livestock (Van Der Werf et al., 2008). Savannas are characterised by a multifaceted strata of vegetation, where an open $\mathrm{C}_{3}$-woody canopy of trees and shrubs overlies a continuous $\mathrm{C}_{4}$-grass-dominated understorey, occur in regions that experience a seasonal wet-dry climate and have low topographic relief and infertile soils (Scholes and Archer, 1997). For simplicity, in this paper all woody plants are referred to as trees, while grasses include all herbaceous vegetation. Savanna vegetation structure (defined by the ratio of woody to herbaceous cover) is further modulated by disturbance events (predominantly fire) that create demographic bottlenecks, preventing canopy closure that results in an open, woody system (Scholes and Archer, 1997). Indeed, fire disturbance is a defining characteristic of savannas, particularly for mesic regions (mean annual precipitation (MAP) $>650 \mathrm{~mm}$ ), potentially holding the ecosystem in a "metastable" state, such that if fire were excluded this open $\mathrm{C}_{3} / \mathrm{C}_{4}$ system would likely shift to a closed $\mathrm{C}_{3}$ forest or woodland (Bond et al., 2005; Sankaran et al., 2005b). The role of fire in modulating vegetation structure allows savannas to occur across a broad demographic continuum, where the density of woody biomass is coupled to the annual amount of rainfall (Hutley et al., 2011; Lehmann et al., 2011). These environmental traits and behaviours therefore mark savannas as one of the most complex terrestrial biomes on the planet, and understanding the vegetation dynamics and underlying processes of this ecosystem type (especially in response to future global change) has proven a challenging task for the ecosystem modelling community (House et al., 2003; Scheiter et al., 2013; Scheiter and Higgins, 2007).

Terrestrial biosphere models (TBMs) are defined here as bottom-up modelling approaches that simulate coupled dynamics of water, energy, carbon and, in some cases, nutri- ents in vegetation and soils. These models have mostly underperformed when modelling fluxes from savanna ecosystems (Whitley et al., 2016). TBMs range from stand models, which simulate specific ecosystems in detail, up to dynamic global vegetation models (DGVMs), which can simulate ecosystem composition and structure, biogeochemical processes and energy exchange and the spatial distribution of multiple ecosystems at regional to global scales (Scheiter et al., 2013). Consequently, TBMs collectively operate over different temporal and spatial scales and employ processes of different scope in simulating ecosystem dynamics. However, common to all TBMs is that they are governed by the same biophysical principles of energy and mass transfer that determines the dynamics of plant life (Pitman, 2003), and this review will focus on the performance of this suite of models. Consequently, the predictive capability of different TBMs at determining the exchange of water, energy and carbon between the surface and atmosphere should be convergent within a reasonable degree of error (Abramowitz, 2012). However, model intercomparison and benchmarking studies have shown that many TBMs are unable to meet reasonable levels of expected performance as a result of a systematic misrepresentation of key ecosystem processes (Abramowitz et al., 2008; Best et al., 2015; Blyth et al., 2011; Mahecha et al., 2010).

While the reasons for this are in some cases specific to the model, a general question can be formed about whether the current generation of TBMs has the predictive capability to adequately simulate savanna fluxes. Additionally, if limitations do exist, are they a result of an incorrect parameterisation of physical parameters (e.g. root depth, maximum RuBisCO activity, soil properties), the inadequate or absent biophysical processes (e.g. phenology, root-water uptake, impacts of fire), the challenge of simulating stochastic events linked to disturbance or a combination of these factors? Particular attributes that characterise savanna environments, such as frequent fire disturbance, highly seasonality available soil water and the annual recurrence of $\mathrm{C}_{4}$ grasses (which, except for grasslands, are absent in other biomes), are not universally represented in most model frameworks. While some TBMs have been specifically designed with savanna dynamics (e.g. Coughenour, 1992; Haverd et al., 2016; Scheiter and Higgins, 2009; Simioni et al., 2000), some are simply modified agricultural models (Littleboy and Mckeon, 1997), with most TBMs attempting to capture savanna fluxes through calibration to observed time series data and ad hoc substitutions of missing processes (Whitley et al., 2016). Furthermore, little has been done to investigate why simulating savanna dynamics has fallen outside the scope and capability of many TBMs, such that these problems can be identified and used in ongoing model development.

In this paper, we review the current state of modelling fluxes of mass and energy from savanna ecosystems and how application of models to this ecosystem may challenge current-generation TBMs. We start with an overview of the 
global savanna complex and the many floristic assemblages that fall under this definition. Moreover, we discuss how the distinct characteristics, dynamics and regional differences among global savanna types may have implications for future global change. We then outline how some of the defining physical processes of savannas are commonly misrepresented in TBMs. Finally, we conclude with a discussion on model evaluation and benchmarking for this ecosystem and show that eddy flux measurements in combination with observations from multiple data sources (PhenoCams, remote sensing products, inventory studies) are essential to capture the seasonality of fluxes from soil, grasses and tree components and to capture the high frequency of disturbance events that perturb the carbon cycle in savanna ecosystems.

\section{The savanna biome}

\subsection{Characteristics and global extent}

At a global scale, biome distributions typically conform to climatic and soil envelopes and current and future distributions are predictable based on climate and ecosystem physiology. However, savannas occur in climatic zones that also support grasslands and forests (Bond et al., 2005; Lehmann et al., 2011), a characteristic that poses major challenges for TBMs and DGVMs. Savannas occur across the tropical to sub-tropical equatorial latitudes occupying a significant portion of the terrestrial land surface in seasonal wet-dry climates (Fig. 1). Savannas are therefore associated with many ecoclimatic regions and are the second-largest tropical ecosystem after rainforests with a global extent of 15.1 million $\mathrm{km}^{2}$, which comprises almost half of the African continent (Menaut, 1983); 2.1 million $\mathrm{km}^{2}$ of the Cerrado, Campos and Caatinga ecoregions in South America (Miranda et al., 1997); 1.9 million $\mathrm{km}^{2}$ of the Australian tropical north (Fox et al., 2001); and parts of peninsular India, Southeast Asia (Singh et al., 1985), California and the Iberian Peninsula (Ryu et al., 2010a).

While the structure of vegetation in these regions has converged towards a formation of mixed $\mathrm{C}_{3}$ trees and $\mathrm{C}_{4}$ grasses, the extensive geographical range of savanna gives rise to a wide range of physiognomies and functional attributes with multiple interacting factors, such as seasonality of climate, hydrology, herbivory, fire regime, soil properties and human influences (Walter, 1973; Walter and Burnett, 1971). Savannas exhibit tree-grass ratios that vary from near-treeless grasslands to open forest savanna with high tree cover (Torello-Raventos et al., 2013). These savanna assemblages can shift to grassland or forest in response to changes in fire regime, grazing and browsing pressure as well as changing levels of atmospheric $\mathrm{CO}_{2}$ (Franco et al., 2014), and modelling this structural and functional diversity is challenging (Moncrieff et al., 2016b). Lehmann et al. (2011) quantified the different extents of savanna globally, showing that for each continent they occupy distinctly different climate spaces. For example, South American savannas are limited to a high but narrower range of MAP ( $\sim 1000$ to $2500 \mathrm{~mm})$, while African and Australian savannas occur over a lower but wider range of MAP ( $\sim 250$ to $2000 \mathrm{~mm})$ and are further separated by strong differences in interannual rainfall variability and soil nutrient content (Bond, 2008). Furthermore, Lehmann et al. (2014) showed that different interactions between vegetation, rainfall seasonality, fire and soil fertility occur on each continent and act as determinants of aboveground woody biomass.

\subsection{Conceptual models of tree and grass coexistence}

Savannas consist of two coexisting but contrasting life forms: tree and grasses. These life forms can be considered as mutually exclusive given their differing fire responses and shade tolerances, as well as their competitive interactions, with grasses typically outcompeting trees for water and nutrients when their roots occupy the same soil horizons (Bond, 2008). Ecological theory would suggest exclusion of one or the other life forms and not their coexistence, which is a defining characteristic of savanna (Sankaran et al., 2004). Over the last 5 decades, numerous mechanisms have been proposed to explain tree-grass coexistence (Bond, 2008; Lehmann et al., 2011; Lehmann and Parr, 2016; Ratnam et al., 2011; Scholes and Archer, 1997; Walter and Burnett, 1971). Contrasting conceptual models have been largely supported by empirical evidence, but no single model has emerged that provides a generic mechanism explaining coexistence across the three continents of the tropical savanna biome (Lehmann et al., 2014). Ecological models can be broadly classified into two categories: (1) competition-based models that feature spatial and temporal separation of resource usage by trees and grasses that minimise interspecific competition enabling the persistence of both life forms and (2) demographic-based models in which mixtures are maintained by disturbance that results in bottlenecks in tree recruitment and/or limitations to tree growth that enables grass persistence.

Root-niche separation models suggest there is a spatial separation of tree and grass root systems that minimises competition, with grasses exploiting upper soil horizons and trees developing deeper root systems, i.e. Walter's two-layer hypothesis (Walter and Burnett, 1971). Trees rely on excess moisture (and nutrient) draining from surface horizons to deeper soil layers. Phenological separation models invoke differences in the timing of growth between trees and grasses. Leaf canopy development and growth in many savanna trees occurs prior to the onset of the wet season, often before grasses have germinated or initiated leaf development. As a result, trees can have exclusive access to resources at the beginning of the growing season, with grasses more competitive during the growing season proper. Given their deeper root systems, tree growth persists longer into the dry season, providing an added period of resource acquisition at a time 

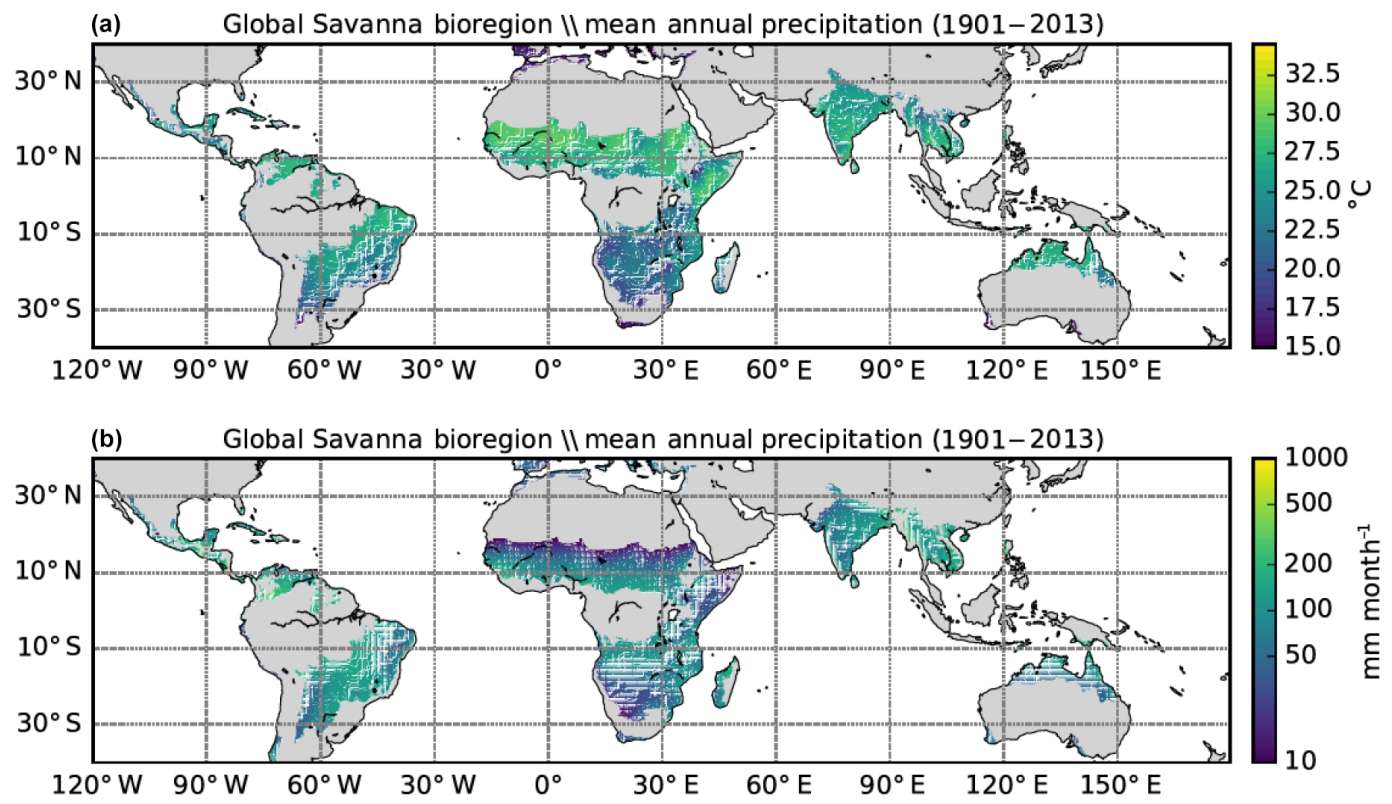

Figure 1. Global maps of (a) mean annual temperature and (b) mean annual rainfall for the period 1901 to 2015, determined from the CRU TS v. 3.23 dataset (Harris et al., 2014). The dataset has been clipped to the eco-floristic regions that approximate the global extent of savannas using the following plant functional types: tropical moist deciduous forest, tropical dry forest, sub-tropical dry forest and tropical shrubland (Ruesch and Gibbs, 2008).

when grasses may be senescing. However, grasses are better able to exploit pulses of resources such as surface soil moisture and nitrogen following short-term rainfall events, particularly important processes regulating semi-arid savanna (Chesson et al., 2004). The spatial and temporal separation of resource usage is thought to minimise competition, also enabling coexistence. Other competition models suggest that tree density becomes self-limiting at a threshold of available moisture and/or nutrient, and they are thus unable to completely exclude grasses. These models assume high rainfall years favour tree growth and recruitment, with poor years favouring grasses and high interannual variability of rainfall maintaining a relatively stable equilibrium of trees and grasses over time (Hutley and Setterfield, 2008).

In many savannas, root distribution is spatially separated, with mature trees exploiting deeper soil horizons as the competitive root-niche separation model predicts. In semi-arid savannas investment in deep root systems may seem counterintuitive, as rainfall events tend to be sporadic and small in nature, with little deep drainage. In this case, surface roots are more effective at exploiting moisture and mineralised nutrients following these discrete events and shallow-rooted grasses tend to have a faster growth response than trees to these pulse events (Jenerette et al., 2008; Nielsen and Ball, 2015).

There are marked differences in how regional flora (primarily woody species) have evolved functional traits to operate within their respective climate space (Lehmann et al., 2014; Cernusak et al., 2011; Eamus, 1999) and major distinc- tions can be drawn between the savanna flora of Africa, Australia and South America. Canopies of the African and South American savanna tree species are predominantly characterised by deciduous woody species that are in most cases (although not always) shallow-rooted and follow a short-term growth strategy that maximises productivity while environmental conditions are favourable (Bowman and Prior, 2005; Lehmann et al., 2011; Scholes and Archer, 1997; Stevens et al., 2017). In contrast, mesic savanna canopies of northern Australia are dominated by deep-rooted, evergreen Eucalyptus and Corymbia woody species that favour a long-term strategy of conservative growth that is insured against an unpredictable climate (Bowman and Prior, 2005; Eamus et al., 1999, 2001).

Consequently, the functional traits that support deciduous, evergreen or annual strategies have a major impact on the water and carbon exchange of savanna. For example, Australian mesic savanna tree canopies operate at almost constant rates of assimilation and transpiration all year round due to their deep and extensive root system and ability to make adjustments to canopy leaf area in times of stress (O'Grady et al., 1999). In these savannas, root competition between both trees and grass roots in upper soil layers is apparent, contrary to predictions of niche-separation models that would predict that tree and grass competition for water and nutrients would be intense. This system serves as an example of where both root-niche and phenological separation are likely to be occurring (Bond, 2008) and highlights the fact that savanna ecosystems cannot be simply reduced to gen- 
eralised plant functional type (PFT) and applied globally in land surface model (LSM) or DGVM frameworks (Moncrieff et al., 2016a). Region-specific PFTs may be required to fully capture the distinctly different dynamics that are occurring across the ensemble of savanna biomes.

Demographic-based models of tree-grass coexistence view savannas as meta-stable ecosystems, where a range of stable states is possible, but the ecosystem can be deflected from an equilibrium with climate and soil due to a combination of frequent disturbances (fire and herbivory), resource limitation (soil moisture and soil nutrients) and growing conditions, in particular temperature (Lehmann et al., 2014). In this paradigm, demographic-based models suggest that moisture and nutrient partitioning is not the sole driver of coexistence and that determinants of tree demographics and recruitment processes ultimately set tree-grass ratios. Fire, herbivory and climatic variability are fundamental drivers of tree recruitment and growth, with high levels of disturbance resulting in demographic bottlenecks that constrain recruitment and/or growth of woody components and grass persistence results. At high rainfall sites, in the absence of disturbance, savanna tends towards forest. Alternatively, high levels of disturbance, particularly fire and herbivory, can push the ecosystem towards a more open canopy or grassland; this ecosystem trajectory is more likely at low rainfall sites.

\subsection{Determinants of savanna structure}

The inherent complexity in savanna function is evident when savanna structure is correlated with environmental factors. Sankaran et al. (2005a) examined the relationship between tree cover and mean annual rainfall with a large scatter of tree cover observed at any given rainfall for African savannas. Rainfall set an upper limit of savanna tree cover, with cover below this due to the interaction of other determinants such as herbivory, site characteristics (drainage, nutrient availability and temperature) and fire frequency reducing tree cover and biomass below a maximum for a given rainfall. Lehmann et al. $(2011,2014)$ took this approach further and examined "savanna-limiting" mechanisms across tropical Africa, Australia and South America. Their analysis suggested that tropical landscapes consist of mosaics of closed-canopy forest, savanna and grasslands, suggesting that the limits of savanna are not simply determined by climate and soils alone. Over the entire range of environmental conditions in which savannas occur, some fraction of the land surface is "not savanna" (Lehmann et al., 2011), suggesting that savannas are not necessarily a stable-state ecosystem.

A promising alternative approach of some recent models is to allow savanna composition to emerge from environmental selection from a mixture of PFTs or trait combinations, reflecting global diversity in savanna vegetation (e.g. Haverd et al., 2016; Scheiter and Higgins, 2009; Scheiter et al., 2013; Smith et al., 2001). As an example, the HAVANA model allows traits such as tree and grass phenology, leaf area, rooting depth and relative cover to emerge from incident meteorological variations and their effect on the evolving ecosystem state (Haverd et al., 2016). Because traits define the response of the vegetation to climate, it is important that they are themselves adequately represented in TBMs.

\subsection{Potential impacts of climate change}

Projected global increases in both temperature and the variability of precipitation patterns as a result of anthropogenic climate change are expected to lead to significant changes in the structure and diversity of global terrestrial ecosystems (IPCC, 2013; Rogers and Beringer, 2017). This will make modelling ecosystem distributions and biogeochemical fluxes under these transient conditions difficult, challenging TBMs in how they represent the response of the savanna ecosystem to structural shifts in vegetation through $\mathrm{CO}_{2}$ fertilisation, increased rainfall seasonality, changes in vapour pressure deficiet and changing fire dynamics (Beringer et al., 2015).

Savannas may be susceptible to small perturbations in climate and could potentially shift towards alternate closedforest or open-grassland states as a result (Scheiter and Higgins, 2009). The total carbon pool of some savannas can be considered as modest when compared with other ecosystems (e.g. rainforests; Kilinc and Beringer, 2007). However, in terms of net primary productivity (NPP), tropical savannas and grasslands make up a significant proportion, contributing ca. $30 \%$ of annual global NPP (Grace et al., 2006). A shift in the savanna state towards a more closed system may lead to these regions becoming a substantially larger carbon sink (Higgins et al., 2010). Observations of increased woody vegetation cover (woody encroachment) in many semi-arid ecosystems and savannas worldwide over recent decades have been attributed to positive effects of increased atmospheric $\mathrm{CO}_{2}$ on plant water use effects (Donohue et al., 2009; Fensholt et al., 2012; Liu et al., 2015). Models suggest that such effects are predicted to continue in the future. $\mathrm{CO}_{2}$ fertilisation is also expected to favour the more responsive $\mathrm{C}_{3}$ vegetation, leading to the competitive exclusion of $\mathrm{C}_{4}$ grasses via suppressed grass growth and reduced fire impacts (Bond et al., 2005). Model projections by Scheiter and Higgins (Scheiter and Higgins, 2009) and Higgins and Scheiter (Higgins and Scheiter, 2012) suggest future range shifts of African savanna into more arid climates as a consequence of elevated $\mathrm{CO}_{2}$, with concurrent transformation of current savanna habitats to forests under a stationary rainfall assumption. Recent evidence underscores the significant role of savannas in the global carbon cycle (Ahlström et al., 2015; Haverd et al., 2016; Poulter et al., 2014).

The response of savanna structure and function to changes in precipitation patterns is highly uncertain (Rogers and Beringer, 2017). Scheiter et al. (2015) investigated the effect of variable rainfall seasonality, projecting modest to large increases in aboveground biomass for savannas in northern 


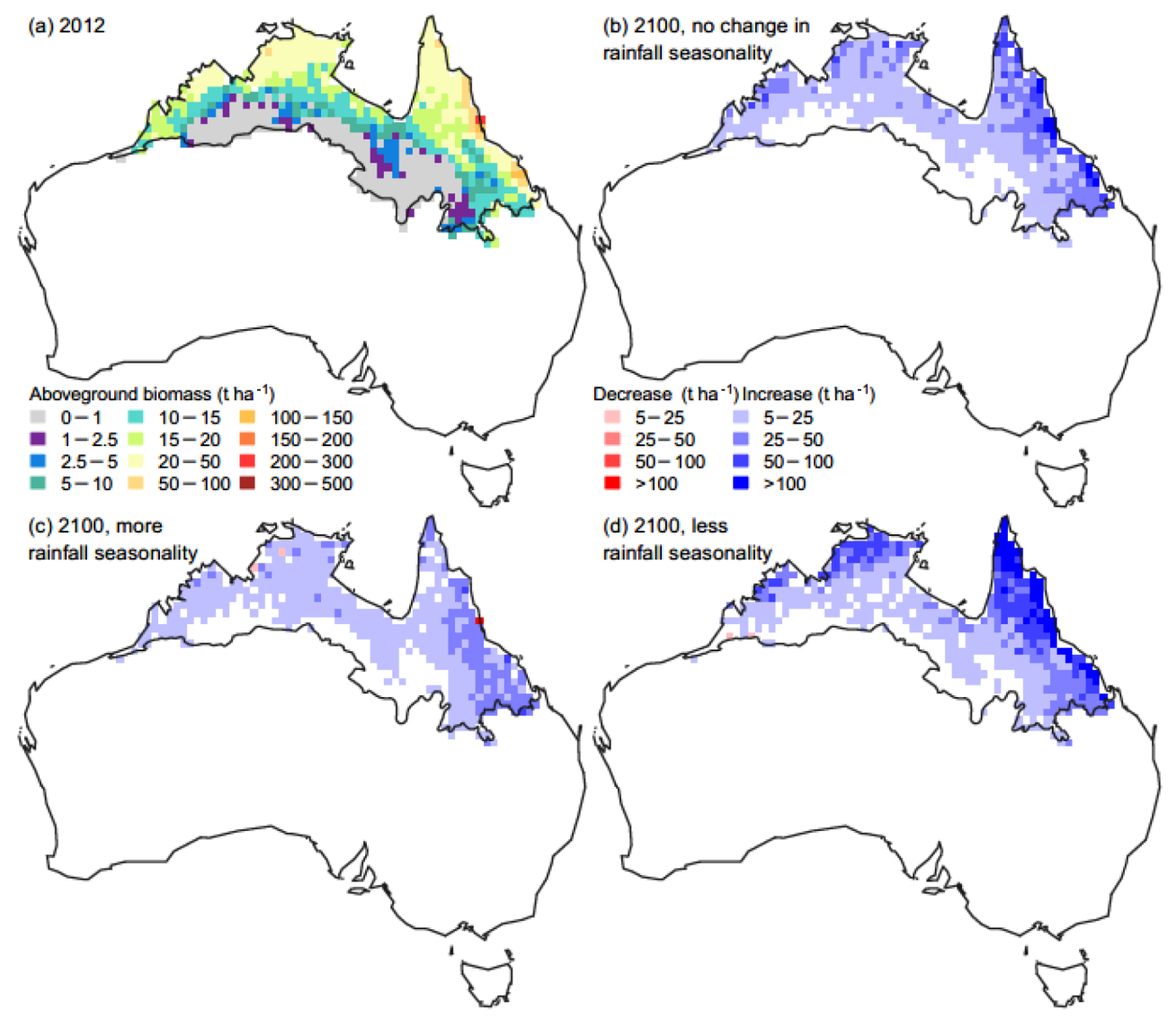

Figure 2. Predicted changes to aboveground biomass over the period of 2012 to 2100 for the Australian savanna region following three scenarios of projected rainfall seasonality according to IPCC SRES A1B (IPCC, 2007). The simulations were conducted using an adaptive dynamic global vegetation model (aDGVM) and predicts how (a) present-day (2012) aboveground biomass changes, when (b) rainfall seasonality does not change, (c) rainfall seasonality increases and (d) rainfall seasonality decreases over the forecast period. In all cases, the aboveground biomass of the Australian savanna region increases, with the magnitude of change determined by the degree of seasonality. Reprinted with permission from Scheiter et al. (2015).

Australia. The authors showed that woody biomass in this region increased despite significant changes to precipitation regimes, being predominantly driven by $\mathrm{CO}_{2}$ fertilisation and rainfall seasonality determining the magnitude of the increase (Fig. 2; Scheiter et al., 2015). However, some studies have indicated that while increased rainfall seasonality may have a small effect in mesic savanna systems, it may potentially act as an opposing effect to woody encroachment in semi-arid savanna systems (Fensham et al., 2009; Hiernaux et al., 2009). For example, Fensham et al. (2009) have shown significant tree mortality to occur as a result of drought in a semi-arid savannas in southwest Queensland, suggesting that severe water stress may counteract the positive effect of $\mathrm{CO}_{2}$ fertilisation on ecosystem carbon balance. Alternatively, forest dieback as a result of increased rainfall seasonality and more frequent drought occurrence may lead to an expansion of savanna distribution in some regions. For example, simulations of the Amazon basin have projected a possible conversion of rainforest to savanna in eastern Amazonia as a re- sult of forest dieback induced by severe water stress and fire disturbance (Cox et al., 2004; Malhi et al., 2009).

Increased warming and changes to rainfall seasonality are expected to alter the interaction between climate, fire and savannas in the future (Beringer et al., 2015), but we leave discussion of savanna fire dynamics and the ability of TBMs to simulate this process until later in this paper. Permanent shifts in the structure and physiology of the savanna complex as a result of climate change are expected to have a major impact on the exchange of water, energy and carbon that occurs in this system, which in turn ultimately affects global biogeochemical cycling and climate (Beringer et al., 2015; Pitman, 2003).

\section{The capability of TBMs to simulate mass and energy exchange from savanna ecosystems}

The misrepresentations of ecosystem processes are particularly evident in savannas, for which many TBMs have nei- 
ther been developed for nor tested on (Baudena et al., 2015; Cramer et al., 2001; Whitley et al., 2016). Seasonal competition and access to belowground resources (soil moisture and nutrients), impacts of browsing and grazing and stochastic disturbance events (fire) are less prevalent in other ecosystems and are therefore not well represented (or even missing) in many TBMs (House et al., 2003; Whitley et al., 2016). Other stochastic events common in savanna environments are precipitation pulses that in semi-arid savanna, drive production and respiration processes (Huxman et al., 2004; Williams et al., 2009). High spatial and temporal variability of pulse events, coupled with the differential responses of tree and grasses complicates application of TBMs in savannas. Precipitation pulses are particularly significant in semiarid ecosystems and pulse size determines the relative response of ecosystem respiration $(\mathrm{Re})$ and gross primary production (GPP), with large events driving high rates of Re that proceed any response in GPP and the ecosystem may switch to source of $\mathrm{CO}_{2}$ to the atmosphere for a period post-event (Huxman et al., 2004). The annual C balance can be determined by the frequency, magnitude and duration of pulse events (Cleverly et al., 2013).

Conventional TBMs still lack this capability and tend to underestimate $\mathrm{Re}$ and overestimate $\mathrm{Ra}$ in semi-arid regions (Mitchell et al., 2011) and therefore have limited application for biomes in the seasonally dry tropics, which in turn becomes a large source of uncertainty in future global studies (Scheiter and Higgins, 2009). However, we believe that incorporating key processes that drive savanna dynamics into current-generation TBMs has great potential, considering that even small modifications can lead to large gains in performance (Feddes et al., 2001; Whitley et al., 2011). It is clear from the above background and discussion that the ecological processes in savannas are numerous, detailed, complex and important as they can all have differential responses to environmental drivers. We suggest that most of the detailed ecological processes become emergent properties within model frameworks. Therefore we do not attempt to capture everything but rather we have identified phenology, root-water uptake and fire disturbance as three critical processes in savannas that deserve special consideration in modern TBMs as explained below.

\subsection{Phenology}

Phenology is an expression of the seasonal dynamics of the structural vegetation properties that define their growing season and ultimately their productivity (Moore et al., 2016a). Here we limit our discussion to the phenology of leaf cover. In seasonally dry climates phenology is driven by soilmoisture availability, and the length of the growing season for shallow rooting plants is determined by the seasonality of rainfall (Kanniah et al., 2010; Ma et al., 2013; Scholes and Archer, 1997). Plants respond differently to water availability, such that phenology is a function of the dominant species within the ecosystem. Deciduous trees and annual grasses are photosynthetically active during the wet season only and respectively senesce or become dormant at the beginning of the dry season, while evergreen trees may remain permanently active throughout the year, potentially responding to soil-moisture depletion by gradually reducing their canopy leaf area (Bowman and Prior, 2005). These dynamics are critically important, as they control the amount and seasonality of carbon uptake and water use. In TBMs, ecosystem phenology is typically represented in one of two ways. The first is via direct prescription of this information as an additional input to the model, where observations of leaf area index (LAI; either in situ measurements or satellite-derived products) are used to express the change in ecosystem canopy cover over time (Whitley et al., 2011). The second is as a prognostic determination using a growth sub-module, where carbon allocation and leaf metabolic activity are simulated and dependent upon the time-varying conditions of temperature and soil-water availability (Scheiter and Higgins, 2009). Prescription of phenology from observed LAI dynamics requires an accurate determination of the separate tree and grass components from bulk ecosystem LAI to be feasible for savanna ecosystems (Whitley et al., 2011). In many cases, this separation is assumed to be static, ignoring the different seasonal changes in tree and grass cover over time (Scholes and Archer, 1997). In fact, no models that we are aware of dynamically partition LAI as it is prescribed. Donohue et al. (2009) offer an a priori method that can determine separate tree and grass LAI signals. This method assumes that the high variability in the bulk signal is attributed to herbaceous vegetation, such that the remaining, less variable signal is attributed to woody vegetation (Fig. 3). A prescription of separate tree and grass LAI inputs was found to be necessary for simulating water and carbon exchange for a mesic savanna site in northern Australia (Whitley et al., 2011) and for determining a reduced error estimate of the Australian continental water and carbon balance (Haverd et al., 2013) to which savannas contribute significantly. The major drawback to prescribing LAI as a model input is that the model's scope is limited to hindcast applications. Because this information is supplied to the model, the floristic structure and its evolution over time is fixed and cannot respond to changing environmental conditions (e.g. shifts in precipitation patterns) that are likely to have an impact on the tree-grass demography (Ma et al., 2013). Consequently, a dynamic approach where savanna phenology is explicitly simulated and dynamically responds to climate and disturbance offers a more promising path forward.

Allocation-growth schemes allow models to express phenology in terms of the evolution of carbon investment in leaf area over time, limited by the availability of resources for growth (Haverd et al., 2016). These schemes effectively work by distributing assimilated carbon (via NPP) to the root, stem and leaf compartments of the simulated plant, where allocation to the leaf is dependent on the plant being metabolically 


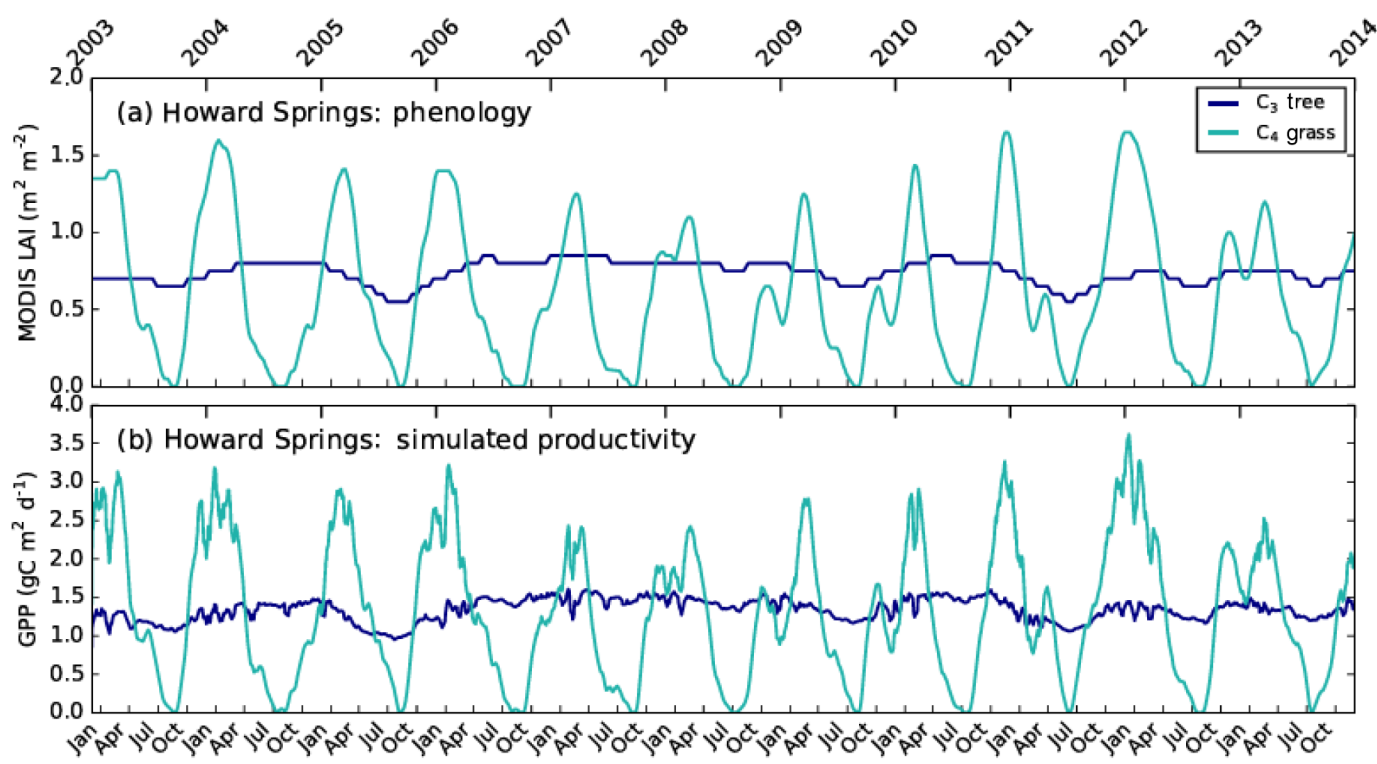

Figure 3. Representation of how changes to (a) tree and grass phenology determines changes in (b) savanna gross primary productivity (GPP) for an Australian mesic savanna. Time-varying signals of tree and grass LAI (a) are determined from a MODIS bulk LAI product using the method of Donohue et al. (2009) and are prescribed as inputs to the soil-plant-atmosphere (SPA) model to predict separate tree and grass GPP. Data and model outputs are from Whitley et al. (2016).

active or dormant (Cramer et al., 2001). In some TBMs, allocation to these compartments is a fixed ratio (set according to plant functional type) and metabolic leaf activity is defined through a set of threshold bioclimatic indicators (e.g. photoperiod, moisture availability and temperature) that determine whether conditions are favourable for photosynthesis (Jolly et al., 2005). However, more recent advances use an alternative approach of dynamically guiding allocation towards the compartment that most limits a plant's growth (Scheiter and Higgins, 2009) or dynamically optimising daily allocation to maximise long-term NPP and control the competitive balance between trees and grasses (Haverd et al., 2016). The latter approach, based on optimality theory (Raupach, 2005), is related to the approach followed by Schymanski et al. (2009), who assumed that vegetation dynamically optimises its properties (root system and foliage) to maximise its long-term net carbon profit. These approaches, which assume a more dynamic coupling between allocation and phenology, allow plant form and community structure to evolve in response to changes in resource availability (light, water or carbon) over time, with phenology becoming an emergent property of this process. Dynamic allocation schemes enable a TBM to answer questions regarding how changing climate or elevated atmospheric $\mathrm{CO}_{2}$ concentrations may alter structural properties of the ecosystem and the resultant feedbacks on water, carbon and energy cycling (Scheiter and Higgins, 2009; Schymanski et al., 2015).

\subsection{Root-water access and uptake}

The root zone is critically important in maintaining water and carbon fluxes, as it defines an ecosystem's accessible belowground resources and vulnerability to prolonged dry periods (De Kauwe et al., 2015). Savannas occur in seasonally dry climates where productivity is primarily limited by dry season water availability (Kanniah et al., 2010, 2011, 2012), which is largely determined by plant regulation of water transport (through leaf stomatal conductance and stem capacitance) and the root zone water storage capacity and access (distribution of fine-root biomass (Eamus et al., 2002). Coordination of the whole soil-root-leaf-atmosphere pathway in response to the highly seasonal climate is critical to the survival of savanna plants and is intrinsically linked to their phenology. Partitioning of root-water uptake is a key component of competition models describing tree-grass coexistence as described above. For example, deciduous and annual savanna species have shallow root profiles (approx. 0.5 to $2 \mathrm{~m}$ ) and highly conductive vascular systems to maximise productivity during the wet season (February and Higgins, 2010). In contrast, evergreen savanna species invest in highly regulated hydraulic architectures and deep root systems $(>2 \mathrm{~m})$ that can access deep soil-water stores to maintain continuous productivity throughout the dry season (Bowman and Prior, 2005). It is therefore critically important that the specific root system and hydraulic architectures of savanna species be adequately represented in models to simulate water and carbon fluxes of this system. 
Soil and plant hydraulic traits such as rooting depth and distribution, stem hydraulic resistance and sand and clay contents are typically represented as fixed parameters in TBMs. Of these traits, the root profile acts as the first-order control on soil-water supply and therefore determines the capability of a simulated plant to remain active through rain-free periods (Eamus et al., 1999). The root profile within a soil column is generally modelled as an exponentially declining root-surface area with depth, the limit of which extends to some prescribed level. Although some models are capable of dynamically determining the size of the root profile as an emergent property of productivity and climate (e.g. Haverd et al., 2016; Schymanski et al., 2009), more typically the maximum rooting depth is fixed at approximately 1.5 to $2.0 \mathrm{~m}$ (Whitley et al., 2016). However, studies have shown that woody plants in semi-arid or seasonally dry climates (particularly those in Australia) exhibit deep root systems to remain active during prolonged dry periods (Duursma et al., 2011; Hutley et al., 2000; O'Grady et al., 1999). Numerous modelling studies have shown that a rooting profile of significant depth $(>2 \mathrm{~m})$ is required to achieve good model-data agreement (Fisher et al., 2007; Haxeltine and Prentice, 1996; Schymanski et al., 2009; Whitley et al., 2016, 2011). While characterisation of the rooting depth in savanna modelling exercises may be seen as a matter of correct parameterisation rather than one of systematic process, its role as a firstorder control on water supply in seasonally water-limited systems gives it significant weight in the overall determination of carbon uptake. Furthermore, long-term responses of rooting depth to climate change or elevated atmospheric $\mathrm{CO}_{2}$ concentrations may substantially alter structure, resource use and carbon uptake of savanna ecosystems (Schymanski et al., 2015). Consequently, rooting depths that sufficiently represent either deciduous or evergreen tree species need to be considered when modelling savannas.

Directly coupled to the characterisation of the root zone is the systematic process by which soil water is extracted by the root system. The process of root-water uptake in TBMs has been simulated using numerous schemes. One approach assumes that the amount of extracted water by roots is a function of the root density distribution within the soil column and is expressed through an additional sink term to the Richards equation, which represents the flow of water in an unsaturated soil (Wang et al., 2011). In such schemes, rootwater uptake may be weighted by the distribution of fine-root biomass in the soil, such that soil layers with the greatest density of fine-root biomass largely determine the soil-water status of the plant, its stomatal behaviour and, therefore, its sensitivity to soil drying (Wang et al., 2011). The exponential decay function conventionally used to describe the root profile in most TBMs (an exception is Schymanski et al., 2009) can result in simulated stomatal behaviour that is heavily weighted towards the moisture content of the upper soil profile, making them highly sensitive to drought (De Kauwe et al., 2015). In reality, the active root distribution of savan- nas is not static, or so limited, but responds dynamically to wherever water is available. For example, eucalypts occurring in Australian mesic savannas invest in "dual-root" systems that are capable of switching their root activity between subsurface and subsoil respectively to access water continually during both wet and dry seasons (Chen et al., 2004). Alternative root-water uptake schemes do exist that describe a more dynamic response to long-term changes in soil conditions. One such scheme by Williams et al. (2001) considers root activity to change over time and be concentrated towards parts of the root zone where the plant can sustainably extract the maximal amount of available water. Consequently, this scheme effectively weighs soil-water status over the distribution of fine-root biomass, such that simulated root-water uptake dynamically responds to the wetting and drying of the soil profile over time (Fig. 4). Another alternative approach by Schymanski et al. (2008) allows the root zone to dynamically adjust the vertical distribution of root biomass in the profile to balance canopy water demand while minimising structural costs of maintaining such a root system. These alternate schemes offer a more dynamic approach to modelling the hydraulic architecture of species occurring in savannas and other semi-arid ecosystems and have demonstrated high predictive skill in these environments (Schymanski et al., 2008, 2009; Whitley et al., 2011). Therefore, given the distinct seasonality of savanna ecosystems, dynamic rootwater extraction schemes are needed to simulate how the root zone responds to the evolution of soil-water supply over time.

It should be noted that the above discussion on root-water uptake is one based on relatively simple model processes. However, savanna ecosystems have much more complex interactions across the soil-root-stem-leaf-atmosphere continuum. Additional processes such as adaptive changes in root architecture across seasonal and interannual timescales, rhizosphere-root interactions, hydraulic redistribution, plant stem water storage and limitations on leaf function due to water demand across soil-root-stem-leaf-atmosphere continuum (Lai and Katul, 2000; Steudle, 2000; Vrugt et al., 2001) may also be important in simulating root-water uptake.

\subsection{Disturbance}

Ecosystem structure and function in seasonally dry tropical systems such as savanna are strongly shaped by environmental disturbance, such as persistent herbivory pressures, frequent low-impact fire events and infrequent highimpact cyclones (Bond, 2008; Hutley and Beringer, 2011) that shape tree demographics. Fires have a significant impact on land surface exchange and vegetation structure and contribute to greenhouse gas emissions through the consumption of biomass (Beringer et al., 1995, 2015). Fire has the capacity to alter land surface exchange fluxes through the removal of functional leaf area (reduced LAI) and the blackening of the surface (reduced albedo), temporarily reducing net carbon uptake (Beringer et al., 2003, 2007) and altering the atmo- 

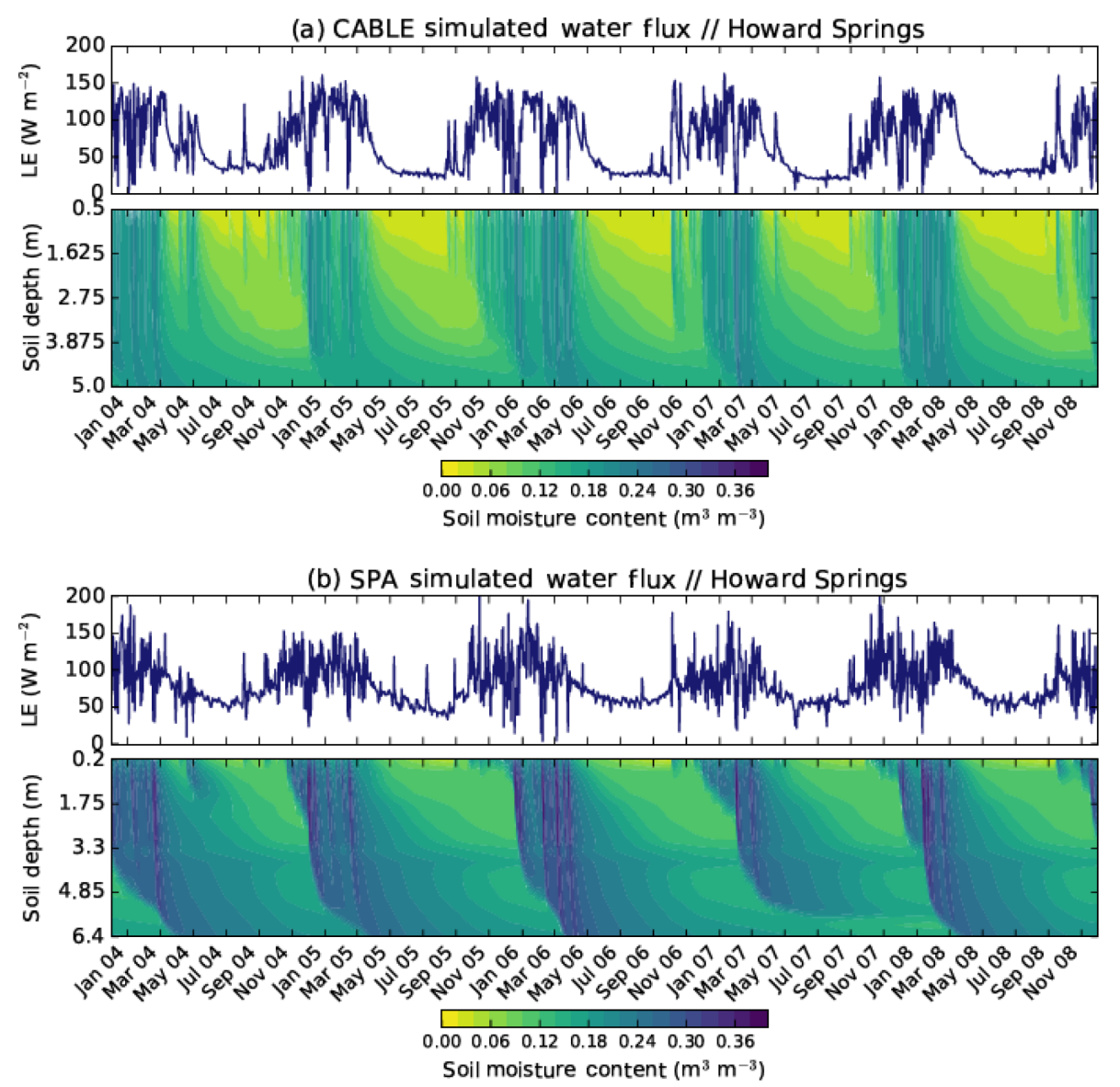

Figure 4. Simulated differences in total ecosystem latent energy (LE) and the resultant evolution of soil-moisture content through the soil profile over time for a mesic Australian savanna site. Simulations were conducted using two different terrestrial biosphere models (TBMs) that use different root-water extraction schemes. Panel (a) shows outputs of savanna water flux using the Community Atmosphere Biosphere Land Exchange (CABLE) model, where soil-water extraction is controlled by the density of the fine-root biomass. Panel (b) shows outputs of savanna water flux from the soil-plant-atmosphere (SPA) model, where soil water is dynamically extracted from where it is available. Model outputs are from Whitley et al. (2016).

spheric boundary layer to affect convective cloud formation and precipitation (Görgen et al., 2006; Lynch et al., 2007). Regarding vegetation structure, fire influences the competitive balance between tree and grass demographics, suppressing recruitment of woody saplings to adults and thereby deflecting the system from reaching canopy closure (Beringer et al., 2015; Higgins et al., 2000). Work by Bond et al. (2005) underlines the potential effect of removing fire from the savanna system, with substantial increases in woody biomass and major structural shifts towards closed forests. This is further supported by more empirical studies involving fire exclusion experiments and showing similar tendencies towards woody dominance (Bond and Van Wilgen, 1996; Scott et al., 2012). Given that future climate projections point to predict higher temperatures and less precipitation for sub-tropical regions (Rogers and Beringer, 2017) the representation of short- and long-term impacts of fire on savanna structure and function in TBMs may be important in understanding how savanna landscapes may respond to changes in fire frequency and intensity (Bond et al., 2005).

Fire is commonly simulated as a stochastic process, with the probability of occurrence increasing with the accumulation of litterfall and grass biomass (fuel loads), combined with dry and windy environmental conditions that promote ignition (generally through lightning; Kelley et al., 2014). The simulated amount of biomass consumed after an ignition event differs among models. Recent advances in simulating savanna fire processes have led to more complete representations of the complex interaction between fire and woody vegetation and how this shapes savanna structure. For example, Scheiter and Higgins (2009) consider a "topkill" probability that suppresses woody plant succession if fire intensity is of a critical magnitude determined by the plant's fire-resisting functional traits (e.g. height, stem diameter, bark thickness). This scheme allows fire to directly shape the savanna tree population through the dynamics of woody establishment, 
resprouting and mortality. Additionally, Kelley et al. (2014) have similarly considered how fire-resisting functional traits of woody vegetation alter the fire dynamics of seasonally dry environments. It should be noted that both studies do not consider anthropogenic ignition events, whereas recent work by Scheiter et al. (2015) suggests that fire management can be simulated using fixed fire return intervals.

Many TBMs simulate fire as an instantaneous event through emissions and removal of biomass but may not consider the transient effects that fire has on land surface after the event has occurred. It has been demonstrated previously that these post-fire effects on canopy surface mass and energy exchange can be significant, with fire indirectly suppressing productivity by ca. $16 \%\left(+0.7 \mathrm{tC} \mathrm{ha}^{-1} \mathrm{yr}^{-1}\right.$; Fig. 5; Beringer et al., 2007). During this period, resprouting rather than climate drives productivity, with respiration exceeding photosynthesis as a result of the regenerative cost of replacing damaged or lost stems and leaf area (Cernusak et al., 2006). In fact, many modelling analyses of savannas dynamics have removed the post-fire periods completely from any assessment of performance, such that evaluation has been limited to periods where the model is considered to be "fit for purpose" (Whitley et al., 2016, 2011). Fire is an integral part of savanna dynamics; it is important to include fire events in the analysis of savanna carbon and water fluxes or model performance. Furthermore, an accurate and robust representation of fire effects on savanna ecosystems is needed to answer questions about how savanna dynamics may change under future climate scenarios, as fire regimes have significant impacts on the carbon balance of these systems (Beringer et al., 2015).

Other disturbance processes such herbivory pressures and impact of cyclones have limited to no representation in models. The removal of aboveground biomass through grazing and browsing, is commonly represented as a set fraction of cover or productivity that is removed over time according to the degree of local agricultural pressures, but has been represented dynamically in some models (e.g. Pachzelt et al., 2015). Grazing and browsing are of central importance in many of the world's savannas and like fire, strongly influence cover and productivity (Bond and Keeley, 2005). The importance of herbivory as a determinant varies between savanna regions, and appears to largely reflect the abundance of large herbivores present. In parts of Africa, woody vegetation density has sometimes been reduced by large herbivores, for example uprooting of trees by elephants when browsing (Asner et al., 2016; Laws, 1970).

Bond and Keeley (2005) suggested that browsing is analogous to fire because once saplings escape a flame or browsing height they are beyond the reach of most mammal herbivores. Invertebrates are also significant herbivores, particularly grasshoppers, caterpillars, ants and termites. Mammal herbivores are typically categorised as grazers, browsers or mixed feeders, who can vary their diet depending on food availability. Large herbivores can lead to changes in species composition, woody vegetation density and soil structure.
Browsers such as giraffes can reduce woody seedling and sapling growth, thereby keeping them within a fire-sensitive heights for decades. Reductions in grass biomass following grazing leads to a reduction of fuel and thus fire frequency and intensity, enhancing the survival of saplings and adult tress (Bond, 2008). Fire also affects herbivory as herbivores may favour post-fire vegetation regrowth.

Termite pressures have also been shown to suppress productivity (Hutley and Beringer, 2011), but this loss may be too small to be considered as a significant consumer of biomass in TBMs. No models that the authors are aware of simulate the effect of cyclones on vegetation dynamics in tropical systems despite their impact on long-term ecosystem structure and productivity. Cyclones are infrequent but highimpact disturbance events that occur in any mesic savanna that lies close to the coastline and can effectively "restart" the savanna system through the mass removal of woody biomass (Hutley et al., 2013). Hutley and Beringer (2011) have shown that for an Australian mesic savanna, a bimodal distribution of the tree class sizes at the site indicates two major recruitment events that corresponds with two of the last great cyclones to occur in the region. Despite the immediate and significant loss of woody biomass during those events, recovery was possible and pushed this site to a carbon sink over many decades (Beringer et al., 2007). Despite the impact that cyclones have on savanna structure it is somewhat understated in the literature, possibly due to the integrated loss in productivity over long periods being small (Hutley et al., 2013) as well as the difficulty in simulating cyclone frequency and intensity at landscape scales at present or in the future. While few models have the capability to simulate the full spectrum of environmental disturbance effects on savanna ecosystems explicitly, the significant modulating impact they have on savanna structure and function flags these processes as a high priority in future model development.

\section{Testing and developing models for application in savannas}

Given that there are strong indications that critical savanna processes are likely misrepresented in current-generation TBMs, there is a clear need for further model testing and evaluation to be conducted for this ecosystem. Savannas have been the subject of improved research over the past 2 decades, resulting in a good and evolving understanding of their complicated structure, function and contribution to global biogeochemical cycling (Higgins and Scheiter, 2012; Lehmann et al., 2014; Sankaran et al., 2005b; Scholes and Archer, 1997). Despite this, our increased understanding of savanna dynamics has not been properly translated into many modern TBMs, with the effect of major deficiencies in modelling this ecosystem (Whitley et al., 2016). Consequently, there is still a great necessity for continuous, consistent and objective studies to test and develop how savanna dynam- 


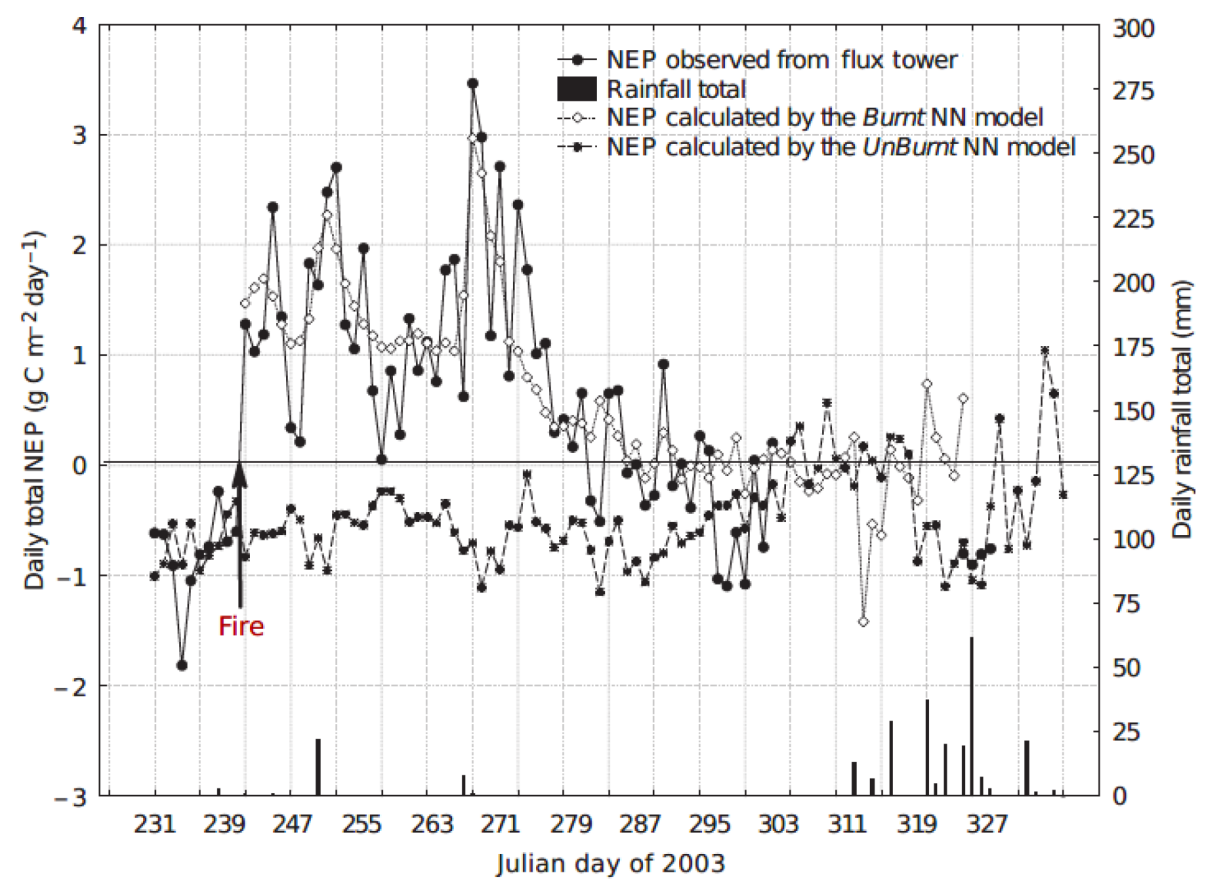

Figure 5. The nonlinear response of net ecosystem productivity (NEP) as the canopy regenerates after a fire event in 2003 at an Australian mesic savanna site. Fire disturbance of a sufficient intensity suppresses productivity, pushing the savanna state from sink to source over a period of 70 days at this site, as the rate of respiration exceeds the rate of assimilation due to resprouting costs. Empirical models created using an artificial neural network (NN) describe the "UnBurnt" and "Burnt" canopy NEP responses over the same period, and their difference estimates the loss of canopy productivity as a consequence of fire. Reprinted with permission from Beringer et al. (2007).

ics are represented and simulated. Below we highlight how datasets from multiple sources that include eddy flux towers, satellites and in situ studies can inform model development and be used in evaluation and benchmarking studies.

\subsection{Datasets to inform model development}

Eddy-covariance (EC) systems that observe the instantaneous response of water, energy and carbon exchange to variability in climate and the evolution of this response over time provide crucial information on which to test and develop TBM application in savanna ecosystems (Beringer et al., 2016, 2017). Turbulent fluxes measured by EC systems that include net ecosystem exchange and latent and sensible heat are common model outputs, such that this information is commonly used to validate TBMs. Local meteorological forcing (e.g. shortwave irradiance (SW), air temperature, rainfall) that is concurrently measured with the turbulent fluxes by other instruments (rainfall and temperature gauges, radiation sensors, etc.) are common model inputs and are used to drive TBMs. Additionally, both turbulent fluxes and meteorological forcing are measured at the same temporal and ecosystem scale at which TBMs are commonly run (Aubinet et al., 2012). Consequently, these datasets offer an unparalleled capability in diagnostic model evaluation (Abramowitz, 2012; Balzarolo et al., 2014; Mahecha et al., 2010). The use of EC datasets to evaluate TBMs and inform further development has been a long-running practice within the ecosystem modelling community, with particular success being reported for some savanna studies in Australia (Barrett et al., 2005; Haverd et al., 2013, 2016, Schymanski et al., 2007, 2009, Whitley et al., 2016, 2011). Here we outline two opportunities of using EC systems in assessing model skill for savanna ecosystems.

The first of these addresses the problem that EC datasets represent the integrated sum of turbulent fluxes for the entire system (i.e. soil, grass, shrubs and trees) that are not easily separated. Assessing model performance using bulk measurements does not consider the separate responses of the functionally different $\mathrm{C}_{3}$ tree and $\mathrm{C}_{4}$ grass components that respond differently to climate (Whitley et al., 2016, 2011). However, a recent study by Moore et al. (2016b) has shown for a mesic savanna site in Australia that separate observations of canopy and understorey fluxes can be determined by using a "dual-tower" EC system that observes turbulent fluxes at reference points above and beneath the canopy (Fig. 6). Datasets such as this provide a valuable resource to analyse the skill of separate model processes, i.e. simulation of tree and grass leaf gas exchange, and test the degree of model equifinality (Bevan and Freer, 2001) at predicting the bulk ecosystem flux. A further collection of coupled overand understorey EC datasets is therefore critically needed to 
verify that simulated tree and grass dynamics are correctly represented in TBMs.

The second opportunity addresses the issue of savanna landscape heterogeneity. Savannas are not a homogeneous PFT but rather a continuum of changing tree and grass demographics that shift biogeographically with rainfall and other factors (Ma et al., 2013). Ecological gradient studies, such as the Kalahari Transect (Scholes et al., 2004) and North Australian Tropical Transect (NATT; Hutley et al., 2011), have shown turbulent fluxes along a declining rainfall gradient to be strongly linked to structural changes in vegetation (Beringer et al., 2011a, b). In essence, the spatial response to a systematic changes in rainfall (or other resources or disturbance intensities) represents the possible future temporal response to changing climate, such that transects can be used to evaluate TBMs by their ability to emulate the full spectrum of savanna behaviour rather than at just one point. A recent model intercomparison study by Whitley et al. (2016) used turbulent flux observations sampled along the NATT to evaluate a set of six TBMs and documented only poor to moderate performances for those savanna sites. Model evaluation studies that test model predictive skill across both time and space are therefore crucial to project how savannas dynamically respond to changing climate.

While EC systems provide valuable datasets on which to test and develop models, they are unable to provide a complete evaluation, as they cannot completely capture long-term temporal and spatial scale features (e.g. demographic structural shifts in vegetation) or provide detail on underlying ecosystem processes (e.g. root-water dynamics and carbon allocation; Abramowitz, 2012; Haverd et al., 2013; Keenan et al., 2012). Additional sources of data and their collection are therefore critical to informing how well models are representing the specific dynamics that unique to savannas. Model inversion studies have shown EC datasets give significant constraint to predictions of NPP, but extra ancillary data that are informative of other underlying processes were required to further constrain uncertainty (Haverd et al., 2013; Keenan et al., 2012). Here, we suggest how each of the three critical savanna processes highlighted in this paper can potentially be tested in addition to EC datasets. Satellite-derived estimates of remotely sensed near-surface reflectance (Ma et al., 2013; Ryu et al., 2010b) and digital imagery from "PhenoCams" (Moore et al., 2016a; Sonnentag et al., 2012) provide a good resource for testing simulated phenology, particularly the "green-up" and "brown-down" phases. Additionally, Advanced Very High Resolution Radiometer (AVHRR) data can provide "burnt area" maps that quantify the frequency of fire events, which can inform the probability of occurrence in simulated fire dynamics. Above- and belowground carbon inventory studies (Chen et al., 2003; Kgope et al., 2010) provide highly valuable sources of information in how plants allocate their resources for growth, which can test the efficacy of TBM allocation scheme. Digital soil maps also provide an excellent resource in parameterising simulated soil pro- files (e.g. Isbell, 2002; Sanchez et al., 2009). However, the spatial resolution of these data products can be coarser than operating resolution of many TBMs, such that site-level measurements should be used when possible. Excavation studies that quantify savanna tree root systems (Chen et al., 2004) and soil-moisture probes installed to greater depths $(>2 \mathrm{~m})$ are informative about the evolution of the soil-root zone over time (e.g. surface root density, root depth), and such data may be critical to understanding whether current rootwater extraction schemes in TBMs are capable of simulating the dry season response of savanna tree species (Whitley et al., 2016). Other useful approaches for elucidating how and where plants gain their water include sap flow measurements (Zeppel et al., 2008), gas chambers (Hamel et al., 2015) and soil-plant-water experiments (Midwood et al., 1998). In additional, hydrogen and oxygen stable isotope ratios of water within plants provide new information on water sources, interactions between plant species and water use patterns under various conditions (see review by Yang et al., 2010).

Finally, localised observations of plant traits such as leaf mass per area, stomatal conductance $\left(g_{\mathrm{s}}\right)$ and tree height are needed to inform a better parameterisation of savannaspecific PFTs (Cernusak et al., 2011). For example, specific leaf-level information such as RuBisCO activity $\left(V_{\mathrm{cmax}}\right)$ and RuPB regeneration $\left(J_{\max }\right)$ for both $\mathrm{C}_{3}$ and $\mathrm{C}_{4}$ plants are critically needed to inform the Farquhar leaf photosynthesis models (Farquhar et al., 1980), while information on $g_{\mathrm{s}}$ and leaf water potential $\left(\Psi_{\text {leaf }}\right)$ is important in parameterising the many stomatal conductance models used in TBMs (Ball et al., 1987; Medlyn et al., 2011; Williams et al., 1996). Leaf capacitance and water potential data are also critically important in characterising model sensitivity to drought (Williams et al., 2001), but this information is severely lacking for savannas.

Given that there are many interacting effects occurring in savannas, an integration of multiple data sources is therefore necessary for a more complete evaluation of how well TBMs perform in this environment. We recommend that future EC studies, particularly along transects as mentioned above, should include intensive field campaigns that are targeted towards a more complete characterisation of the site. This would include root excavations and the collection of plant trait measurements that sample such data within the footprint of an EC tower. Collaborative research networks, such as those of TERN (Terrestrial Ecosystem Research Network), NEON (National Ecological Observatory Network) and SAEON (South African Environmental Observation Network), that have the resources and infrastructure to conduct such campaigns will be needed to meet these demands for more observational data.

\subsection{Model evaluation and benchmarking}

Multiple dynamic processes drive savanna structure and function, and an understanding of the causes and reasons 


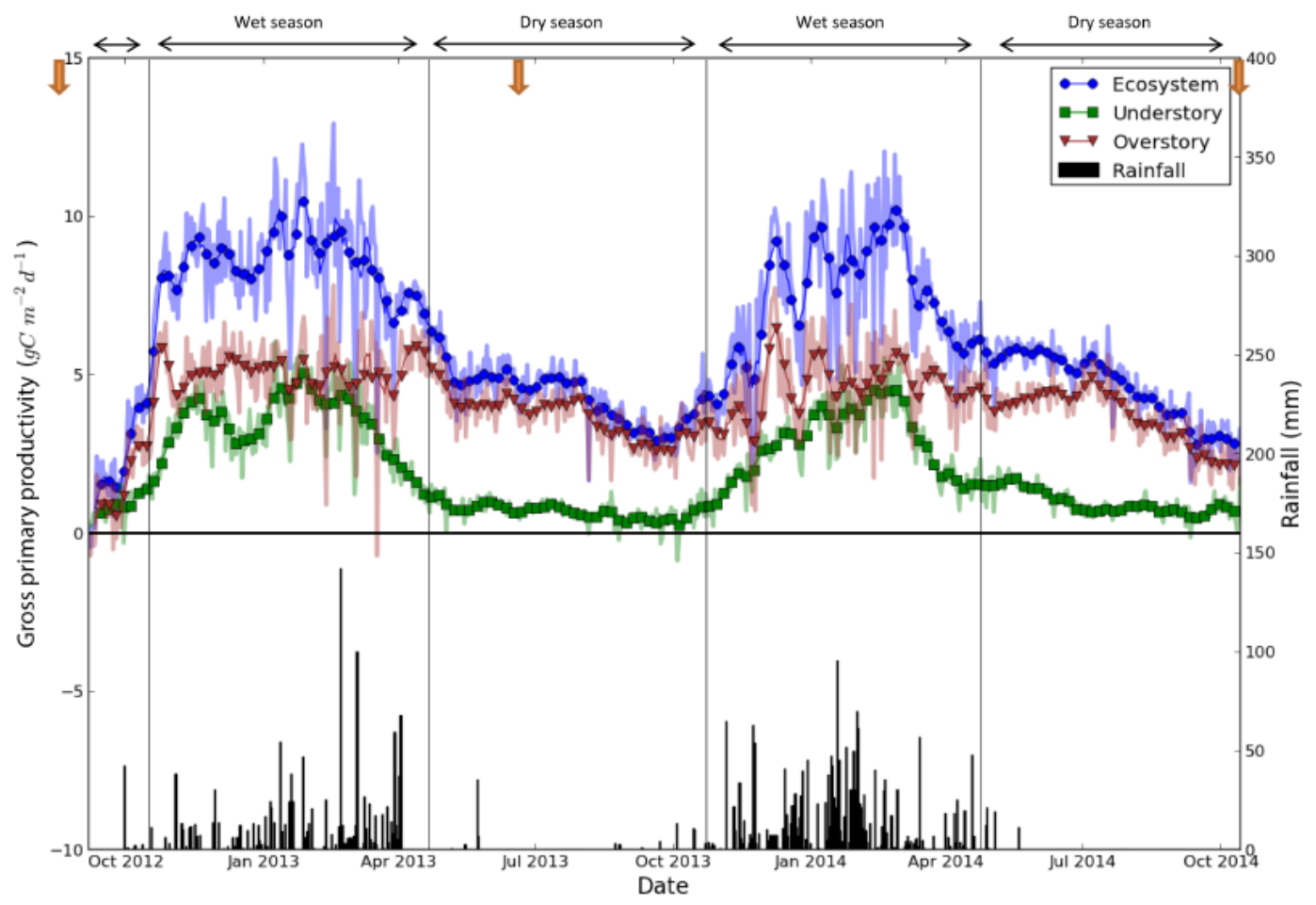

Figure 6. Smoothed (10-day running mean) time series of understorey (red), overstorey (green) and total ecosystem (red) gross primary productivity (GPP) for a mesic savanna site in northern Australia. Rainfall is represented as black bars. Negative and positive signs represent the savanna state as a carbon source or sink respectively, and orange arrows depict the occurrence of fire events. Data products for total ecosystem and understorey GPP are inferred from observations of net ecosystem exchange using eddy-covariance towers at heights of 23 and $5 \mathrm{~m}$ respectively. Overstorey GPP is determined as the difference between the ecosystem and the understorey. Reprinted with permission from Moore et al. (2016b).

for why TBMs systematically misrepresent this ecosystem is paramount to future development. Consequently, a complete diagnostic evaluation of model performance in savanna ecosystems requires more than just simple model-model and model-data comparisons where "good performance" is determined from a score in a given metric (e.g. a high correlation between observed and predicted values). Instead evaluation should also consider parsimony, physical representativeness and "out-of-sample" capability of the model itself (Abramowitz et al., 2008). A holistic evaluation of the biophysical, biogeochemical and ecological processes represented in TBMs has therefore been the aim of many international model intercomparison projects, with some notable examples being the Project for the Intercomparison of Land surface Parameterization Schemes (PILPS; Pitman, 2003) and the Coupled Carbon Cycle Climate Model Intercomparison Project (C4MIP; Friedlingstein et al., 2006). Most recently the International Land Model Benchmarking Project (ILAMB) has been established to holistically assess the major components of TBMs, through a model-data comparison framework that utilises standardised benchmarking and performance metrics to identify critical model deficiencies and guide future development (Luo et al., 2012).
A major goal of ILAMB is to support the development of open-source software that can facilitate such a benchmarking framework by the international modelling community. The Protocol for the Analysis of Land Surface models (PALS; http://www.pals.unsw.edu.au/) has been recently developed to meet the formalism outlined by ILAMB, using standardised experiments to benchmark TBMs in terms of how well they should be expected to perform, based on their complexity and the information used to drive them (Abramowitz, 2012). In brief, PALS uses a set of empirical benchmarks to fulfil the role of an arbitrary TBM of increasing complexity by quantifying the amount of information in the meteorological forcing useful to reproduce water, carbon and energy exchange. This gives a point of reference to measure at what level of complexity a TBM is performing by comparison of the statistical performance between model and benchmark (Best et al., 2015). For example, we can assess whether a sophisticated, state-of-the-art DGVM can outperform a simple linear regression against SW at predicting GPP. If the outcome of this test were negative, then this may suggest that the model does not capture the sensitivity of GPP to SW accurately, flagging it as a priority for investigation and development. The important distinction to make with the bench- 

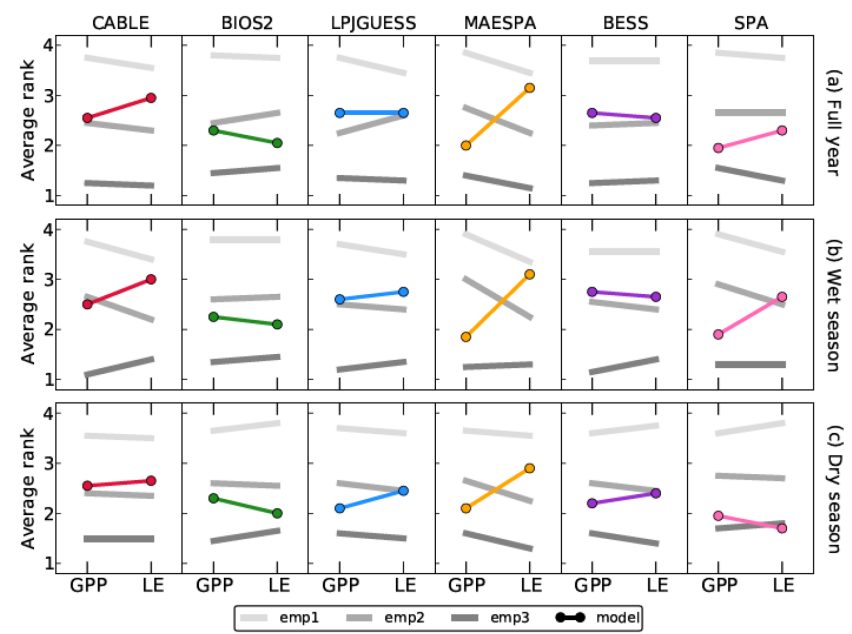

Figure 7. Rank plot showing the average performance of six terrestrial biosphere models (TBMs) across the North Australian Tropical Transect (NATT). The closer a model's rank is to 1 , the better its performance is at predicting latent energy (LE) and gross primary productivity (GPP). Empirical benchmarks representing increasing levels of complexity (emp1 <emp2<emp3) are represented as grey lines, and coloured lines denote each model. The lines have no scientific value and are used for visual purposes only. Benchmarking and model evaluation data are from Whitley et al. (2015).

marks is that they have no internal state variables such as soil moisture and temperature or any knowledge of vegetation or soil properties; they represent a purely instantaneous response to the meteorological forcing (Abramowitz et al., 2008). The protocol of PALS meets the four criteria outlined by ILAMB that objectively, effectively and reliably measure the underlying processes of a TBM to improve its predictive skill (Luo et al., 2012). A direct application of this protocol was presented in a model intercomparison study by Whitley et al. (2016), where they assessed the predictive capability of TBMs in savanna ecosystems by comparing model outputs to three simple empirical benchmarks. In this study the authors used six calibrated TBMs to predict ecosystem latent energy and GPP at five savanna sites along the NATT, and found that in almost all cases the LSMs could perform only as well as a multiple linear regression against $\mathrm{SW}$, temperature and vapour pressure deficit (Fig. 7). While an additional assessment of other outputs is required, the study highlighted that there are likely systematic misrepresentations of simulated phenology and root-water access in some of these models (Whitley et al., 2016). This is the first assessment of its kind for investigating how well savanna dynamics are captured by modern TBMs and implies that without further development TBMs may have limited scope as investigative tools for future projections of savanna ecosystems.

\section{Conclusions}

There is a large degree of uncertainty as to what impact climate change may have on the structure and function of savanna ecosystems given their complex interaction with climate. Because TBMs are the only interpreter of vegetation dynamics available to us that can reconcile the combination of effects induced by climate change, their predictive capability at representing savanna dynamics is of significant importance (Scheiter and Higgins, 2009). For TBMs to have the necessary skill required to simulate savannas under both present and future climate, model development must be concentrated towards more adequate representations of phenology, root-water uptake and disturbance dynamics, notably fires. We outline our recommendations below in these areas:

- Phenology: A dynamic representation of how leaf area responds to seasonally changing environment conditions, such that it becomes an emergent property of the coupled dynamics of weather and ecosystem function.

- Root-water uptake: Rooting depth and root distribution profiles that represent the contrasting strategies of trees and seasonal grasses, including their temporal dynamics. Additionally, root-water extraction schemes that can dynamically respond to the wetting and drying of the soil over time, accessing soil water from where it is sustainably available rather than where the highest density of root biomass occurs.

- Disturbances: The role of disturbance (ubiquitous to all savannas) in keeping savanna systems open needs to be accounted for in models. Models need to represent the dynamic processes that capture the effect of fire on savanna composition, particularly in suppressing woody growth. Additionally, recovery periods whether through intense herbivory, fire (re-sprouting) or storm or cyclonic events (re-establishment), such processes should also be considered given the dynamic influence these events have on the long-term carbon balance of savannas.

In addition to the recommended areas for TBM development above, we also stress that any improvements made in the representation of the above processes must be followed with a more complete evaluation and benchmarking of TBMs that considers multiple data sources in order to better constrain model uncertainty. We have highlighted that EC systems provide an unparalleled source of data for testing the predictive capability of TBMs at simulating water and carbon exchange in savannas. The role of regional flux communities, such as the OzFlux network (Baldocchi et al., 2001; Beringer et al., 2016), will be to advance applications of EC systems that target savanna characteristics specifically.

Indeed, more studies are needed that measure overstorey and understorey turbulent fluxes (Moore et al., 2016b), given 
their ability to quantify the contribution of co-dominant tree and grass functional types. Additionally, a greater use of ecological transects as tools for model evaluation are needed to quantify the ability of TBMs to simulate savanna behaviour over changing floristic structure and climate (Hutley et al., 2011). However, additional ecological and physiological measurements are also needed to test modelled representations of root-zone water dynamics, carbon allocation and growth, phenology and the recovery of vegetation after major disturbance events (fire and cyclones), dynamic processes that cannot be verified by EC datasets alone. Facilities such as the Australian Super Site Network (Karan et al., 2016) run by TERN will be critical to the collection of ecophysiological information that can inform how savanna dynamics are represented in TBMs.

Finally, we outline that future model experiments and intercomparison studies that leverage EC and ecophysiological datasets should target each of the three previously mentioned processes individually. These may include rooting depth and water extraction experiments that test the sensitivity of TBMs to the dry season transition period or fire management studies that investigate how the floristic structure in TBMs responds to variable fire frequency. Furthermore, such studies must also be conducted for savanna sites that have well-established datasets to test the processes in question. For example, we expect that any study that attempts to test or improve the representation of fire dynamics in TBMs is to be conducted at a site that has a long-running EC record (given the variable return time of fire events) and a full suite of concurrent ecophysiological measurements that quantifies the response of vegetation under post-fire recovery.

Remote sensing observations suggest tree cover is increasing and grassland-savanna-forest boundaries are changing (Bond, 2008) and these changes can have large feedbacks to the earth-atmosphere system (Liu et al., 2015). There is still great uncertainty in predicting the future of savanna biomes (Scheiter et al., 2015; Scheiter and Higgins, 2009) and improving how savanna ecosystems are represented by TBMs will likely encompass the consideration of additional processes that have not been mentioned here. This will no doubt include improved understanding of ecological theory that will lead to improvements in modelling ecosystem demographics and tree-grass interaction that will improve DGVMs. However, we believe that by identifying these processes as the cause for degraded model performance in this ecosystem, a road map for future development can be constructed that leverages the availability of rich datasets and current state of knowledge.

Data availability. No data sets were used in this article.

Competing interests. The authors declare that they have no conflict of interest.
Special issue statement. This article is part of the special issue "OzFlux: a network for the study of ecosystem carbon and water dynamics across Australia and New Zealand". It is not associated with a conference.

Acknowledgements. This study was conducted as part of the "Australian Savanna Landscapes: Past, Present and Future" project funded by the Australian Research Council (DP130101566). The support, collection and utilisation of data was completed by the OzFlux network (www.ozflux.org.au) and Terrestrial Ecosystem Research Network (TERN; www.tern.org.au) and funded by the ARC (DP0344744, DP0772981 and DP130101566). PALS was partly funded by the TERN ecosystem Modelling and Scaling infrAStructure (eMAST) facility under the National Collaborative Research Infrastructure Strategy (NCRIS) 2013-2014 budget initiative of the Australian Government Department of Industry. Rhys Whitley was supported through the ARC Discovery Grant (DP130101566). Jason Beringer is funded under an ARC FT (FT110100602). We acknowledge the support of the Australian Research Council Centre of Excellence for Climate System Science (CE110001028). We thank Jason Beringer, Caitlin Moore and Simon Scheiter for their permission to reproduce their results in this study.

Edited by: Dario Papale

Reviewed by: three anonymous referees

\section{References}

Abramowitz, G.: Towards a public, standardized, diagnostic benchmarking system for land surface models, Geosci. Model Dev., 5, 819-827, https://doi.org/10.5194/gmd-5-819-2012, 2012.

Abramowitz, G., Leuning, R., Clark, M., and Pitman, A.: Evaluating the Performance of Land Surface Models, J. Climate, 21, 54685481, https://doi.org/10.1175/2008JCLI2378.1, 2008.

Ahlström, A., Raupach, M. R., Schurgers, G., Smith, B., Arneth, A., Jung, M., Reichstein, M., Canadell, J. G., Friedlingstein, P., Jain, A. K., Kato, E., Poulter, B., Sitch, S., Stocker, B. D., Viovy, N., Wang, Y. P., Wiltshire, A., Zaehle, S., and Zeng, $\mathrm{N}$.: The dominant role of semi-arid ecosystems in the trend and variability of the land CO2 sink, Science, 348, 895-899, https://doi.org/10.1126/science.aaa1668, 2015.

Asner, G. P., Vaughn, N., Smit, I. P. J., and Levick, S.: Ecosystemscale effects of megafauna in African savannas, Ecography, 39, 240-252, https://doi.org/10.1111/ecog.01640, 2016.

Aubinet, M., Vesala, T., and Papale, D.: Eddy Covariance - A Practical Guide to Measurement and Data Analysis, edited by: Aubinet, M., Vesala, T., and Papale, D., Springer Netherlands, Dordrecht, 2012.

Baldocchi, D., Falge, E., Gu, L. H., Olson, R., Hollinger, D., Running, S., Anthoni, P., Bernhofer, C., Davis, K., Evans, R., Fuentes, J., Goldstein, A., Katul, G., Law, B., Lee, X. H., Malhi, Y., Meyers, T., Munger, W., Oechel, W., U, K. T. P., Pilegaard, K., Schmid, H. P., Valentini, R., Verma, S., Vesala, T., Wilson, K. B., and Wofsy, S. C.: FLUXNET: A new tool to study the temporal and spatial variability of ecosystem-scale carbon dioxide, 
water vapor, and energy flux densities [Review], B. Am. Meteorol. Soc., 82, 2415-2434, 2001.

Ball, J. T., Woodrow, I. E., and Berry, J. A.: A model predicting stomatal conductance and its contribution to the control of photosynthesis under different environmental conditions., in Progress in Photosynthesis Research, Martinus-Nijhoff Publishers, Dordrecht, the Netherlands, 221-224, 1987.

Balzarolo, M., Boussetta, S., Balsamo, G., Beljaars, A., Maignan, F., Calvet, J.-C., Lafont, S., Barbu, A., Poulter, B., Chevallier, F., Szczypta, C., and Papale, D.: Evaluating the potential of large-scale simulations to predict carbon fluxes of terrestrial ecosystems over a European Eddy Covariance network, Biogeosciences, 11, 2661-2678, https://doi.org/10.5194/bg-112661-2014, 2014.

Barrett, D. J., Hill, M. J., Hutley, L. B., Beringer, J., Xu, J. H., Cook, G. D., Carter, J. O., and Williams, R. J.: Prospects for improving savanna biophysical models by using multiple-constraints model-data assimilation methods, Aust. J. Bot., 53, 689-714, https://doi.org/10.1071/bt04139, 2005.

Baudena, M., Dekker, S. C., van Bodegom, P. M., Cuesta, B., Higgins, S. I., Lehsten, V., Reick, C. H., Rietkerk, M., Scheiter, S., Yin, Z., Zavala, M. A., and Brovkin, V.: Forests, savannas, and grasslands: bridging the knowledge gap between ecology and Dynamic Global Vegetation Models, Biogeosciences, 12, 18331848, https://doi.org/10.5194/bg-12-1833-2015, 2015.

Beringer, J., Packham, D., and Tapper, N. J.: Biomass burning and resulting emissions in the Northern Territory, Australia, Int. J. Wildl. Fire, 5, 229-235, 1995.

Beringer, J., Hutley, L. B., Tapper, N. J., Coutts, A., Kerley, A., and O'Grady, A. P.: Fire impacts on surface heat, moisture and carbon fluxes from a tropical savanna in northern Australia, Int. J. Wildl. Fire, 12, 333-340, https://doi.org/10.1071/wf03023, 2003.

Beringer, J., Hutley, L. B., Tapper, N. J., and Cernusak, L. A.: Savanna fires and their impact on net ecosystem productivity in North Australia, Glob. Change Biol., 13, 990-1004, https://doi.org/10.1111/j.1365-2486.2007.01334.x, 2007.

Beringer, J., Hutley, L. B., Hacker, J. M., Neininger, B., and Paw U, K. T.: Patterns and processes of carbon, water and energy cycles across northern Australian landscapes: From point to region, Agr. Forest Meteorol., 151, 1409-1416, https://doi.org/10.1016/j.agrformet.2011.05.003, $2011 \mathrm{a}$.

Beringer, J., Hacker, J., Hutley, L. B., Leuning, R., Arndt, S. K., Amiri, R., Bannehr, L., Cernusak, L. A., Grover, S., Hensley, C., Hocking, D., Isaac, P., Jamali, H., Kanniah, K., Livesley, S., Neininger, B., Paw U, K. T., Sea, W., Straten, D., Tapper, N., Weinmann, R., Wood, S., and Zegelin, S.: SPECIAL-Savanna Patterns of Energy and Carbon Integrated across the Landscape, B. Am. Meteorol. Soc., 92, 1467-1485, https://doi.org/10.1175/2011BAMS2948.1, 2011b.

Beringer, J., Hutley, L. B., Abramson, D., Arndt, S. K., Briggs, P., Bristow, M., Canadell, J. G., Cernusak, L. A., Eamus, D., Evans, B. J., Fest, B., Goergen, K., Grover, S. P., Hacker, J., Haverd, V., Kanniah, K., Livesley, S. J., Lynch, A., Maier, S., Moore, C., Raupach, M., Russell-Smith, J., Scheiter, S., Tapper, N. J., and Uotila, P.: Fire in Australian Savannas: from leaf to landscape, Glob. Change Biol., 11, 6641, https://doi.org/10.1111/gcb.12686, 2015.
Beringer, J., Hutley, L. B., McHugh, I., Arndt, S. K., Campbell, D., Cleugh, H. A., Cleverly, J., Resco de Dios, V., Eamus, D., Evans, B., Ewenz, C., Grace, P., Griebel, A., Haverd, V., HinkoNajera, N., Huete, A., Isaac, P., Kanniah, K., Leuning, R., Liddell, M. J., Macfarlane, C., Meyer, W., Moore, C., Pendall, E., Phillips, A., Phillips, R. L., Prober, S. M., Restrepo-Coupe, N., Rutledge, S., Schroder, I., Silberstein, R., Southall, P., Yee, M. S., Tapper, N. J., van Gorsel, E., Vote, C., Walker, J., and Wardlaw, T.: An introduction to the Australian and New Zealand flux tower network - OzFlux, Biogeosciences, 13, 5895-5916, https://doi.org/10.5194/bg-13-5895-2016, 2016.

Beringer, J., McHugh, I., Hutley, L. B., Isaac, P., and Kljun, N.: Technical note: Dynamic INtegrated Gap-filling and partitioning for OzFlux (DINGO), Biogeosciences, 14, 1457-1460, https://doi.org/10.5194/bg-14-1457-2017, 2017.

Best, M. J., Abramowitz, G., Johnson, H. R., Pitman, A. J., Balsamo, G., Boone, A., Cuntz, M., Decharme, B., Dirmeyer, P. A., Dong, J., Ek, M., Guo, Z., Haverd, V., van den Hurk, B. J. J., Nearing, G. S., Pak, B., Peters-Lidard, C., Santanello, J. A., Stevens, L., and Vuichard, N.: The Plumbing of Land Surface Models: Benchmarking Model Performance, J. Hydrometeorol., 16, 1425-1442, https://doi.org/10.1175/JHM-D-14-0158.1, 2015.

Bevan, K. and Freer, J.: Equifinality, data assimilation, and uncertainty estimation in mechanistic modelling of complex environmental systems using the GLUE methodology, J. Hydrol., 249, 11-29, https://doi.org/10.1016/S0022-1694(01)00421-8, 2001.

Blyth, E., Clark, D. B., Ellis, R., Huntingford, C., Los, S., Pryor, M., Best, M., and Sitch, S.: A comprehensive set of benchmark tests for a land surface model of simultaneous fluxes of water and carbon at both the global and seasonal scale, Geosci. Model Dev., 4, 255-269, https://doi.org/10.5194/gmd-4-255-2011, 2011.

Bond, W. J.: What Limits Trees in C 4 Grasslands and Savannas?, Annu. Rev. Ecol. Evol. Syst., 39, 641-659, https://doi.org/10.1146/annurev.ecolsys.39.110707.173411, 2008.

Bond, W. J. and Keeley, J. E.: Fire as a global "herbivore": the ecology and evolution of flammable ecosystems, Trends Ecol. Evol., 20, 387-394, https://doi.org/10.1016/j.tree.2005.04.025, 2005.

Bond, W. J. and Van Wilgen, B. W.: Surviving fires - vegetative and reproductive responses, in Fire and plants, Chapman \& Hall, London, 38-42, 1996.

Bond, W. J., Woodward, F. I., and Midgley, G. F.: The global distribution of ecosystems in a world without fire, New Phytol., 165, 525-538, https://doi.org/10.1111/j.14698137.2004.01252.x, 2005.

Bowman, D. M. J. S. and Prior, L. D.: Why do evergreen trees dominate the Australian seasonal tropics?, Aust. J. Bot., 53, 379-399, 2005.

Cernusak, L. A., Hutley, L. B., Beringer, J., and Tapper, N. J.: Stem and leaf gas exchange and their responses to fire in a north Australian tropical savanna, Plant Cell Environ., 29, 632-646, https://doi.org/10.1111/j.1365-3040.2005.01442.x, 2006.

Cernusak, L. A., Hutley, L. B., Beringer, J., Holtum, J. A. M., and Turner, B. L.: Photosynthetic physiology of eucalypts along a sub-continental rainfall gradient in northern Australia, Agr. Forest Meteorol., 151, 1462-1470, https://doi.org/10.1016/j.agrformet.2011.01.006, 2011. 
Chen, X., Eamus, D., and Hutley, L. B.: Seasonal patterns of fine-root productivity and turnover in a tropical savanna of northern Australia, J. Trop. Ecol., 20, 221-224, https://doi.org/10.1017/S0266467403001135, 2004.

Chen, X. Y., Hutley, L. B., and Eamus, D.: Carbon balance of a tropical savanna of northern Australia, Oecologia, 137, 405-416, https://doi.org/10.1007/s00442-003-1358-5, 2003.

Chesson, P., Gebauer, R. L. E., Schwinning, S., Huntly, N., Wiegand, K., Ernest, M. S. K., Sher, A., Novoplansky, A., and Weltzin, J. F.: Resource pulses, species interactions, and diversity maintenance in arid and semi-arid environments, Oecologia, 141, 236-253, https://doi.org/10.1007/s00442-004-1551-1, 2004.

Cleverly, J., Boulain, N., Villalobos-Vega, R., Grant, N., Faux, R., Wood, C., Cook, P. G., Yu, Q., Leigh, A., and Eamus, D.: Dynamics of component carbon fluxes in a semi-arid Acacia woodland, central Australia, J. Geophys. Res.-Biogeo., 118, 11681185, https://doi.org/10.1002/jgrg.20101, 2013.

Coughenour, M. B.: Spatial modeling and landscape characterization of an African pastoral ecosystem: a prototype model and its potential use for monitoring drought, in Ecological Inidcators, edited by: McKenzie, D. H., Hyatt, D. E., and McDonald, V. J., Elsevier Applied Science, New York, New York, 1, 787810, 1992.

Cox, P. M., Betts, R. A., Collins, M., Harris, P. P., Huntingford, C., and Jones, C. D.: Amazonian forest dieback under climatecarbon cycle projections for the 21 st century, Theor. Appl. Climatol., 78, 137-156, https://doi.org/10.1007/s00704-004-00494, 2004.

Cramer, W., Bondeau, A., Woodward, F. I., Prentice, I. C., Betts, R. A., Brovkin, V., Cox, P. M., Fisher, V., Foley, J. A., Friend, A. D., Kucharik, C., Lomas, M. R., Ramankutty, N., Sitch, S., Smith, B., White, A., and Young-Molling, C.: Global response of terrestrial ecosystem structure and function to $\mathrm{CO} 2$ and climate change: results from six dynamic global vegetation models, Glob. Change Biol., 7, 357-373, https://doi.org/10.1046/j.13652486.2001.00383.x, 2001.

De Kauwe, M. G., Zhou, S.-X., Medlyn, B. E., Pitman, A. J., Wang, Y.-P., Duursma, R. A., and Prentice, I. C.: Do land surface models need to include differential plant species responses to drought? Examining model predictions across a mesic-xeric gradient in Europe, Biogeosciences, 12, 7503-7518, https://doi.org/10.5194/bg-12-7503-2015, 2015.

Donohue, R. J., McVICAR, T. R., and Roderick, M. L.: Climaterelated trends in Australian vegetation cover as inferred from satellite observations, 1981-2006, Glob. Change Biol., 15, 10251039, https://doi.org/10.1111/j.1365-2486.2008.01746.x, 2009.

Duursma, R. A., Barton, C. V. M., Eamus, D., Medlyn, B. E., Ellsworth, D. S., Forster, M. A., Tissue, D. T., Linder, S., and McMurtrie, R. E.: Rooting depth explains [CO2] x drought interaction in Eucalyptus saligna, Tree Physiol., 31, 922-931, https://doi.org/10.1093/treephys/tpr030, 2011.

Eamus, D.: Ecophysiological traits of deciduous and evergreen woody species in the seasonally dry tropics, Trends Ecol. Evol., 14, 11-16, 1999.

Eamus, D., Myers, B., Duff, G., and Williams, D.: Seasonal changes in photosynthesis of eight savanna tree species, Tree Physiol., 19, 665-671, 1999.
Eamus, D., Prior, L., and Figures: Ecophysiology of trees of seasonally dry tropics: Comparisons among phenologies [Review] Caswell H, Adv. Ecol. Res., 32, 113-197, 2001.

Eamus, D., Chen, X., Kelley, G., and Hutley, L. B.: Root biomass and root fractal analyses of an open Eucalyptus forest in a savanna of north Australia, Aust. J. Bot., 50, 31-41, 2002.

Farquhar, G. D., von Caemmerer, S., and Berry, J. A.: A Biochemical Model of Photosynthetic CO2 Assimilation in Leaves of C3 species, Planta, 149, 78-90, 1980.

February, E. C. and Higgins, S. I.: The distribution of tree and grass roots in savannas in relation to soil nitrogen and water, South African J. Bot., 76, 517-523, https://doi.org/10.1016/j.sajb.2010.04.001, 2010.

Feddes, R. A., Hoff, H., Bruen, M., Dawson, T., de Rosnay, P., Dirmeyer, P., and Pitman, A. J.: Modeling Root Water Uptake in Hydrological and Climate Models, B. Am. Meteorol. Soc., 82, 2797-2809, https://doi.org/10.1175/15200477(2001)082<2797:MRWUIH>2.3.CO;2, 2001.

Fensham, R. J., Fairfax, R. J., and Ward, D. P.: Drought-induced tree death in savanna, Glob. Change Biol., 15, 380-387, https://doi.org/10.1111/j.1365-2486.2008.01718.x, 2009.

Fensholt, R., Langanke, T., Rasmussen, K., Reenberg, A., Prince, S. D., Tucker, C., Scholes, R. J., Le, Q. B., Bondeau, A., Eastman, R., Epstein, H., Gaughan, A. E., Hellden, U., Mbow, C., Olsson, L., Paruelo, J., Schweitzer, C., Seaquist, J., and Wessels, K.: Greenness in semi-arid areas across the globe 1981-2007 - an Earth Observing Satellite based analysis of trends and drivers, Remote Sens. Environ., 121, 144-158, https://doi.org/10.1016/j.rse.2012.01.017, 2012.

Fisher, R. A., Williams, M., Da Costa, A. L., Malhi, Y., Da Costa, R. F., Almeida, S,. and Meir, P.: The response of an Eastern Amazonian rain forest to drought stress: results and modelling analyses from a throughfall exclusion experiment, Glob. Change Biol., 13, 2361-2378, https://doi.org/10.1111/j.13652486.2007.01417.x, 2007.

Fox, I. D., Neldner, V. J., Wilson, G. W., Bannink, P. J., Wilson, B. A., Brocklehurst, P. S., Clark, M. J., Dickinson, K. J. M., Beard, J. S., Hopkins, A. J. M., Beeston, G. R., Harvey, J. M., Thompson, E. J., Ryan, T. S., Thompson, S. L., Butler, D. W., Cartan, H., Addicott, E. P., Bailey, L. P., Cumming, R. J., Johnson, D. C., Schmeider, M., Stephens, K. M., and Bean, A. R.: The Vegetation of the Australian Tropical Savannas, Environmental Protection Agency, Brisbane, 2001.

Franco, A. C., Rossatto, D. R., de Carvalho Ramos Silva, L., and da Silva Ferreira, C.: Cerrado vegetation and global change: the role of functional types, resource availability and disturbance in regulating plant community responses to rising $\mathrm{CO} 2$ levels and climate warming, Theor. Exp. Plant Physiol., 26, 19-38, https://doi.org/10.1007/s40626-014-0002-6, 2014.

Friedlingstein, P., Cox, P., Betts, R., Bopp, L., von Bloh, W., Brovkin, V., Cadule, P., Doney, S., Eby, M., Fung, I., Bala, G., John, J., Jones, C., Joos, F., Kato, T., Kawamiya, M., Knorr, W., Lindsay, K., Matthews, H. D., Raddatz, T., Rayner, P., Reick, C., Roeckner, E., Schnitzler, K. G., Schnur, R., Strassmann, K., Weaver, A. J., Yoshikawa, C., and Zeng, N.: Climate-carbon cycle feedback analysis: Results from the C4MIP model intercomparison, J. Climate, 19, 3337-3353, https://doi.org/10.1175/JCLI3800.1, 2006. 
Görgen, K., Lynch, A. H., Marshall, A. G., and Beringer, J.: Impact of abrupt land cover changes by savanna fire on northern Australian climate, J. Geophys. Res., 111, 19106, https://doi.org/10.1029/2005jd006860, 2006

Grace, J., San Jose, J., Meir, P., Miranda, H. S., Montes, R. A., and Jose, J. S.: Productivity and carbon fluxes of tropical savannas, J. Biogeogr., 33, 387-400, https://doi.org/10.1111/j.13652699.2005.01448.x, 2006.

Hamel, P., Mchugh, I., Coutts, A., Daly, E., Beringer, J., and Fletcher, T. D.: Automated Chamber System to Measure Field Evapotranspiration Rates, J. Hydrol. Eng., 20, 4014037, https://doi.org/10.1061/(ASCE)HE.1943-5584.0001006, 2015.

Harris, I., Jones, P. D., Osborn, T. J., and Lister, D. H.: Updated high-resolution grids of monthly climatic observations - the CRU TS3.10 Dataset, Int. J. Climatol., 34, 623-642, https://doi.org/10.1002/joc.3711, 2014.

Haverd, V., Raupach, M. R., Briggs, P. R., Canadell, J. G., Isaac, P., Pickett-Heaps, C., Roxburgh, S. H., van Gorsel, E., Viscarra Rossel, R. A., and Wang, Z.: Multiple observation types reduce uncertainty in Australia's terrestrial carbon and water cycles, Biogeosciences, 10, 2011-2040, https://doi.org/10.5194/bg-102011-2013, 2013.

Haverd, V., Smith, B., Raupach, M., Briggs, P., Nieradzik, L., Beringer, J., Hutley, L., Trudinger, C. M., and Cleverly, J.: Coupling carbon allocation with leaf and root phenology predicts tree-grass partitioning along a savanna rainfall gradient, Biogeosciences, 13, 761-779, https://doi.org/10.5194/bg-13-761-2016, 2016.

Haxeltine, A. and Prentice, I. C.: An equilibrium terrestrial biosphere model based on ecophysiological constraints, resource availability, Global Biogeochem. Cy., 10, 693-709, 1996.

Hiernaux, P., Diarra, L., Trichon, V., Mougin, E., Soumaguel, N., and Baup, F.: Woody plant population dynamics in response to climate changes from 1984 to 2006 in Sahel (Gourma, Mali), J. Hydrol., 375, 103-113, https://doi.org/10.1016/j.jhydrol.2009.01.043, 2009.

Higgins, S. I. and Scheiter, S.: Atmospheric CO2 forces abrupt vegetation shifts locally, but not globally, Nature, 488, 209-212, 2012.

Higgins, S. I., Bond, W. J., and Trollope, W. S. W.: Fire, resprouting and variability: A recipe for grass-tree coexistence in savanna, J. Ecol., 88, 213-229, https://doi.org/10.1046/j.13652745.2000.00435.x, 2000.

Higgins, S. I., Scheiter, S., and Sankaran, M.: The stability of African savannas: insights from the indirect estimation of the parameters of a dynamic model, Ecology, 91, 1682-1692, 2010.

House, J. I., Archer, S., Breshears, D. D., and Scholes, R. J.: Conundrums in mixed woody - herbaceous plant systems, J. Biogeogr., 30, 1763-1777, https://doi.org/10.1046/j.13652699.2003.00873.x, 2003.

Hutley, L. B. and Beringer, J.: Disturbance and climatic drivers of carbon dynamics of a north Australian tropical savanna, in Ecosystem Function in Savannas: Measurement and Modeling at Landscape to Global Scales, edited by: Hill, M. J. and Hanan, N. P., CRC Press, Boca Raton, Flordia, 57-75, 2011.

Hutley, L. B. and Setterfield, S. A.: Savanna, in Encyclopedia of Ecology, 3143-3154, 2008.
Hutley, L. B., O’Grady, A. P., and Eamus, D.: Evapotranspiration from Eucalypt open-forest savanna of Northern Australia, Funct. Ecol., 14, 183-194, 2000.

Hutley, L. B., Beringer, J., Isaac, P. R., Hacker, J. M., and Cernusak, L. a.: A sub-continental scale living laboratory: Spatial patterns of savanna vegetation over a rainfall gradient in northern Australia, Agr. Forest Meteorol., 151, 1417-1428, https://doi.org/10.1016/j.agrformet.2011.03.002, 2011.

Hutley, L. B., Evans, B. J., Beringer, J., Cook, G. D., Maier, S. M., and Razon, E.: Impacts of an extreme cyclone event on landscape-scale savanna fire, productivity and greenhouse gas emissions, Environ. Res. Lett., 8, 045023, https://doi.org/10.1088/1748-9326/8/4/045023, 2013.

Huxman, T. E., Snyder, K. A., Tissue, D., Leffler, A. J., Ogle, K., Pockman, W. T., Sandquist, D. R., Potts, D. L., and Schwinning, S.: Precipitation pulses and carbon fluxes in semiarid and arid ecosystems, Oecologia, 141, 254-268, https://doi.org/10.1007/s00442-004-1682-4, 2004.

IPCC: Contribution of Working Group I to the fifth assessment report of the Intergovernmental Panel on Climate Change, Climate ch., edited by: Stocker, T., Qin, D., Plattner, M., Tignor, M. M. B., Allen, S., Boschung, J., Nauels, A., Xia, Y., Bex, V., and Midgley, P., Cambridge University Press, Cambridge, UK and New York, NY, USA, 2013.

Isbell, R.: The Australian Soil Classification, Revised Edn., CSIRO Publishing, Collingwood, Victoria, 2002.

Jenerette, G. D., Scott, R. L., and Huxman, T. E.: Whole ecosystem metabolic pulses following precipitation events, Funct. Ecol., 22, 924-930, 2008.

Jolly, W. M., Nemani, R., and Running, S. W.: A generalized, bioclimatic index to predict foliar phenology in response to climate, Glob. Change Biol., 11, 619-632, https://doi.org/10.1111/j.13652486.2005.00930.x, 2005.

Kanniah, K. D., Beringer, J., and Hutley, L. B.: The comparative role of key environmental factors in determining savanna productivity and carbon fluxes: A review, with special reference to northern Australia, Prog. Phys. Geogr., 34, 459-490, https://doi.org/10.1177/0309133310364933, 2010.

Kanniah, K. D., Beringer, J., and Hutley, L. B.: Environmental controls on the spatial variability of savanna productivity in the Northern Territory, Australia, Agr. Forest Meteorol., 151, 14291439, https://doi.org/10.1016/j.agrformet.2011.06.009, 2011.

Kanniah, K. D., Beringer, J., North, P., and Hutley, L.: Control of atmospheric particles on diffuse radiation and terrestrial plant productivity: A review, Prog. Phys. Geogr., 36, 209-237, https://doi.org/10.1177/0309133311434244, 2012.

Karan, M., Liddell, M., Prober, S. M., Arndt, S., Beringer, J., Boer, M., and Wardlaw, T.: The Australian SuperSite Network: A continental, long-term terrestrial ecosystem observatory, Sci. Total Environ., 568, 1263-1274, https://doi.org/10.1016/j.scitotenv.2016.05.170, 2016.

Keenan, T. F., Davidson, E., Moffat, A. M., Munger, W., and Richardson, A. D.: Using model-data fusion to interpret past trends, and quantify uncertainties in future projections, of terrestrial ecosystem carbon cycling, Glob. Change Biol., 18, 25552569, https://doi.org/10.1111/j.1365-2486.2012.02684.x, 2012.

Kelley, D. I., Harrison, S. P., and Prentice, I. C.: Improved simulation of fire-vegetation interactions in the Land surface Processes and eXchanges dynamic global vegetation model (LPX-Mv1), 
Geosci. Model Dev., 7, 2411-2433, https://doi.org/10.5194/gmd7-2411-2014, 2014.

Kgope, B., Bond, W. J., and Midgley, G. F.: Growth responses of African savanna trees implicate atmospheric [CO2] as a driver of past and current changes in savanna tree cover, Aust. Ecol., 35, 451-463, https://doi.org/10.1111/j.1442-9993.2009.02046.x, 2010.

Kilinc, M. and Beringer, J.: The spatial and temporal distribution of lightning strikes and their relationship with vegetation type, elevation, and fire sears in the Northern Territory, J. Climate, 20, 1161-1173, https://doi.org/10.1175/jcli4039.1, 2007.

Lai, C.-T. and Katul, G.: The dynamic role of root-water uptake in coupling potential to actual transpiration, Adv. Water Resour., 23, 427-439, https://doi.org/10.1016/S0309-1708(99)00023-8, 2000.

Laws, R. M.: Elephants as Agents of Habitat and Landscape Change in East Africa, Oikos, 21, 1-15, https://doi.org/10.2307/3543832, 1970.

Lehmann, C. E. R. and Parr, C. L.: Tropical grassy biomes: linking ecology, human use and conservation, Philos. T. R. Soc. B, 371, 20160329, https://doi.org/10.1098/rstb.2016.0329, 2016.

Lehmann, C. E. R., Archibald, S. A., Hoffmann, W. A., and Bond, W. J.: Deciphering the distribution of the savanna biome, New Phytol., 191, 197-209, https://doi.org/10.1111/j.14698137.2011.03689.x, 2011.

Lehmann, C. E. R., Anderson, T. M., Sankaran, M., Higgins, S. I., Archibald, S., Hoffmann, W. A., Hanan, N. P., Williams, R. J., Fensham, R. J., Felfili, J., Hutley, L. B., Ratnam, J., San Jose, J., Montes, R., Franklin, D., Russell-Smith, J., Ryan, C. M., Durigan, G., Hiernaux, P., Haidar, R., Bowman, D. M. J. S., and Bond, W. J.: Savanna vegetation-fire-climate relationships differ among continents, Science, 343, 548-552, https://doi.org/10.1126/science.1247355, 2014.

Littleboy, M. and Mckeon, G. M.: GRASP: grass production model, 1997.

Liu, Y. Y., van Dijk, A. I. J. M., de Jeu, R. A. M., Canadell, J. G., McCabe, M. F., Evans, J. P., and Wang, G.: Recent reversal in loss of global terrestrial biomass, Nature Climate Change, 5, 470-474, https://doi.org/10.1038/nclimate2581, 2015.

Luo, Y. Q., Randerson, J. T., Abramowitz, G., Bacour, C., Blyth, E., Carvalhais, N., Ciais, P., Dalmonech, D., Fisher, J. B., Fisher, R., Friedlingstein, P., Hibbard, K., Hoffman, F., Huntzinger, D., Jones, C. D., Koven, C., Lawrence, D., Li, D. J., Mahecha, M., Niu, S. L., Norby, R., Piao, S. L., Qi, X., Peylin, P., Prentice, I. C., Riley, W., Reichstein, M., Schwalm, C., Wang, Y. P., Xia, J. Y., Zaehle, S., and Zhou, X. H.: A framework for benchmarking land models, Biogeosciences, 9, 3857-3874, https://doi.org/10.5194/bg-9-3857-2012, 2012.

Lynch, A. H., Abramson, D., Görgen, K., Beringer, J., and Uotila, P.: Influence of savanna fire on Australian monsoon season precipitation and circulation as simulated using a distributed computing environment, Geophys. Res. Lett., 34, L20801, https://doi.org/10.1029/2007gl030879, 2007

Ma, X., Huete, A., Yu, Q., Coupe, N. R., Davies, K., Broich, M., Ratana, P., Beringer, J., Hutley, L. B., Cleverly, J., Boulain, N., and Eamus, D.: Spatial patterns and temporal dynamics in savanna vegetation phenology across the North Australian Tropical Transect, Remote Sens. Environ., 139, 97-115, https://doi.org/10.1016/j.rse.2013.07.030, 2013.
Mahecha, M. D., Reichstein, M., Jung, M., Seneviratne, S. I., Zaehle, S., Beer, C., Braakhekke, M. C., Carvalhais, N., Lange, H., Le Maire, G., and Moors, E.: Comparing observations and process-based simulations of biosphere-atmosphere exchanges on multiple timescales, J. Geophys. Res.-Biogeo., 115, 1-21, https://doi.org/10.1029/2009JG001016, 2010.

Malhi, Y., Aragão, L. E. O. C., Galbraith, D., Huntingford, C., Fisher, R., Zelazowski, P., Sitch, S., McSweeney, C., and Meir, P.: Exploring the likelihood and mechanism of a climate-change-induced dieback of the Amazon rainforest, P. Natl. Acad. Sci. USA, 106, 20610-2065, https://doi.org/10.1073/pnas.0804619106, 2009.

Medlyn, B. E., Duursma, R. A., Eamus, D., Ellsworth, D. S., Prentice, I. C., Barton, C. V. M., Crous, K. Y., De Angelis, P., Freeman, M., and Wingate, L.: Reconciling the optimal and empirical approaches to modelling stomatal conductance, Glob. Change Biol., 17, 2134-2144, https://doi.org/10.1111/j.13652486.2010.02375.x, 2011.

Menaut, J.: The vegetation of African Savannas, in Tropical savannas, edited by: Bourliére, F., Elsevier, New York, 109-149, 1983.

Midwood, A. J., Boutton, T. W., Archer, S. R., and Watts, S. E.: Water use by woody plants on contrasting soils in a savanna parkland: assessment with $\delta 2 \mathrm{H}$ and $\delta 18 \mathrm{O}$, Plant Soil, 205, 13-24, https://doi.org/10.1023/A:1004355423241, 1998.

Miranda, A. C., Miranda, H. S., Lloyd, J., Grace, J., Francey, R. J., McIntyre, J. A., Meir, P., Riggan, P., Lockwood, R., and Brass, J.: Fluxes of Carbon, Water and Energy over Brazilian Cerrado an Analysis Using Eddy Covariance and Stable Isotopes, Plant. Cell Environ., 20, 315-328, 1997.

Mitchell, S., Beven, K., Freer, J., and Law, B.: Processes influencing model-data mismatch in drought-stressed, firedisturbed eddy flux sites, J. Geophys. Res., 116, G02008, https://doi.org/10.1029/2009JG001146, 2011.

Moncrieff, G. R., Bond, W. J., and Higgins, S. I.: Revising the biome concept for understanding and predicting global change impacts, J. Biogeogr., 43, 863-873, https://doi.org/10.1111/jbi.12701, 2016a.

Moncrieff, G. R., Scheiter, S., Langan, L., Trabucco, A., and Higgins, S. I.: The future distribution of the savannah biome: modelbased and biogeographic contingency, Philos. T. R. Soc. B, 371, 20150311, https://doi.org/10.1098/rstb.2015.031, 2016b.

Moore, C. E., Brown, T., Keenan, T. F., Duursma, R. A., van Dijk, A. I. J. M., Beringer, J., Culvenor, D., Evans, B., Huete, A., Hutley, L. B., Maier, S., Restrepo-Coupe, N., Sonnentag, O., Specht, A., Taylor, J. R., van Gorsel, E., and Liddell, M. J.: Reviews and syntheses: Australian vegetation phenology: new insights from satellite remote sensing and digital repeat photography, Biogeosciences, 13, 5085-5102, https://doi.org/10.5194/bg13-5085-2016, 2016a.

Moore, C. E., Beringer, J., Evans, B., Hutley, L. B., McHugh, I., and Tapper, N. J.: The contribution of trees and grasses to productivity of an Australian tropical savanna, Biogeosciences, 13, 2387-2403, https://doi.org/10.5194/bg-13-2387-2016, 2016 b.

Nielsen, U. N. and Ball, B. A.: Impacts of altered precipitation regimes on soil communities and biogeochemistry in arid and semi-arid ecosystems, Glob. Change Biol., 21, 1407-1421, https://doi.org/10.1111/gcb.12789, 2015.

O'Grady, A. P., Eamus, D., Hutley, L. B., and Grady, A. P. O.: Transpiration increases during the dry season: patterns of tree water 
use in eucalypt open-forests of northern Australia, Tree Physiol., 19, 591-597, 1999.

Pachzelt, A., Forrest, M., Rammig, A., Higgins, S. I., and Hickler, T.: Potential impact of large ungulate grazers on African vegetation, carbon storage and fire regimes, Glob. Ecol. Biogeogr., 24, 991-1002, https://doi.org/10.1111/geb.12313, 2015.

Pitman, A. J.: The evolution of, and revolution in, land surface schemes designed for climate models, Int. J. Climatol., 23, 479510, https://doi.org/10.1002/joc.893, 2003.

Poulter, B., Frank, D., Ciais, P., Myneni, R. B., Andela, N., Bi, J., Broquet, G., Canadell, J. G., Chevallier, F., Liu, Y. Y., Running, S. W., Sitch, S., and van der Werf, G. R.: Contribution of semiarid ecosystems to interannual variability of the global carbon cycle, Nature, 509, 600-603, https://doi.org/10.1038/nature13376, 2014

Ratnam, J., Bond, W. J., Fensham, R. J., Hoffmann, W. A., Archibald, S., Lehmann, C. E. R., Anderson, M. T., Higgins, S. I., and Sankaran, M.: When is a "forest" a savanna, and why does it matter?, Glob. Ecol. Biogeogr., 20, 653-660, https://doi.org/10.1111/j.1466-8238.2010.00634.x, 2011.

Raupach, M. R.: Dynamics and Optimality in Coupled Terrestrial Energy, Water, Carbon and Nutrient Cycles, IAHS Publication, 301, 223-238, 2005.

Rogers, C. D. W. and Beringer, J.: Describing rainfall in northern Australia using multiple climate indices, Biogeosciences, 14, 597-615, https://doi.org/10.5194/bg-14-597-2017, 2017.

Ruesch, A. and Gibbs, H. K.: New IPCC Tier-1 Global Biomass Carbon Map For the Year 2000, Oak Ridge, Tennessee, 2008.

Ryu, Y., Sonnentag, O., Nilson, T., Vargas, R., Kobayashi, H., Wenk, R., and Baldocchi, D. D.: How to quantify tree leaf area index in an open savanna ecosystem: A multi-instrument and multi-model approach, Agr. Forest Meteorol., 150, 63-76, https://doi.org/10.1016/j.agrformet.2009.08.007, 2010a.

Ryu, Y., Baldocchi, D. D., Verfaillie, J., Ma, S., Falk, M., RuizMercado, I., Hehn, T., and Sonnentag, O.: Testing the performance of a novel spectral reflectance sensor, built with light emitting diodes (LEDs), to monitor ecosystem metabolism, structure and function, Agr. Forest Meteorol., 150, 1597-1606, https://doi.org/10.1016/j.agrformet.2010.08.009, 2010b.

Sanchez, P. A., Ahamed, S., Carré, F., Hartemink, A. E., Hempel, J., Huising, J., Lagacherie, P., Mcbratney, A. B., Mckenzie, N. J., De, M., Mendonça-santos, L., Minasny, B., Montanarella, L., Okoth, P., Palm, C. A., Sachs, J. D., Shepherd, K. D., Vågen, T., Vanlauwe, B., Walsh, M. G., Winowiecki, L. A., and Zhang, G.: Digital Soil Map of the World, Science, 325, 6-7, https://doi.org/10.1126/science.1175084, 2009.

Sankaran, M., Ratnam, J., and Hanan, N. P.: Tree-grass coexistence in savannas revisited - insights from an examination of assumptions and mechanisms invoked in existing models, Ecol. Lett., 7, 480-490, https://doi.org/10.1111/j.1461-0248.2004.00596.x, 2004.

Sankaran, M., Hanan, N. P., Scholes, R. J., Ratnam, J., Augustine, D. J., Cade, B. S., Gignoux, J., Higgins, S. I., Le Roux, X., Ludwig, F., Ardo, J., Banyikwa, F., Bronn, A., Bucini, G., Caylor, K. K., Coughenour, M. B., Diouf, A., Ekaya, W., Feral, C. J., February, E. C., Frost, P. G. H., Hiernaux, P., Hrabar, H., Metzger, K. L., Prins, H. H. T., Ringrose, S., Sea, W., Tews, J., Worden, J., and Zambatis, N.: Determinants of woody cover in African savannas, Nature, 438, 846-849, 2005a.
Sankaran, M., Hanan, N. P., Scholes, R. J., Ratnam, J., Augustine, D. J., Cade, B. S., Gignoux, J., Higgins, S. I., Le Roux, X., Ludwig, F., Ardo, J., Banyikwa, F., Bronn, A., Bucini, G., Caylor, K. K., Coughenour, M. B., Diouf, A., Ekaya, W., Feral, C. J., February, E. C., Frost, P. G. H., Hiernaux, P., Hrabar, H., Metzger, K. L., Prins, H. H. T., Ringrose, S., Sea, W., Tews, J., Worden, J., and Zambatis, N.: Determinants of woody cover in African savannas, Nature, 438, 846-849, https://doi.org/10.1038/nature04070, 2005b.

Scheiter, S. and Higgins, S. I.: Partitioning of root and shoot competition and the stability of savannas, Am. Nat., 170, 587-601, https://doi.org/10.1086/521317, 2007.

Scheiter, S. and Higgins, S. I.: Impacts of climate change on the vegetation of Africa: an adaptive dynamic vegetation modelling approach, Glob. Change Biol., 15, 2224-2246, https://doi.org/10.1111/j.1365-2486.2008.01838.x, 2009.

Scheiter, S., Langan, L., and Higgins, S. I.: Nextgeneration dynamic global vegetation models: learning from community ecology, New Phytol., 198, 957-969, https://doi.org/10.1111/nph.12210, 2013.

Scheiter, S., Higgins, S. I., Beringer, J., and Hutley, L. B.: Climate change and long-term fire management impacts on Australian savannas, New Phytol., 205, 1211-1226, https://doi.org/10.1111/nph.13130, 2015.

Scholes, D. and Hall, R.: The carbon budget of tropical savannas; woodlands and grasslands, in Global change: effects on; coniferous forests and grassland, edited by: Breymeyer, A. I., Hall, I. D., Melillo, J. M., and Agren, G. I., Wiley, New York, 69-100, 1996.

Scholes, R. J. and Archer, S.: Tree-grass interactions in savannas, Annu. Rev. Ecol. Syst., 28, 517-544, 1997.

Scholes, R. J., Frost, P. G. H., and Tian, Y.: Canopy structure in savannas along a moisture gradient on Kalahari sands, Glob. Change Biol., 10, 292-302, https://doi.org/10.1046/j.13652486.2003.00703.x, 2004.

Schymanski, S. J., Roderick, M. L., Sivapalan, M., Hutley, L. B., and Beringer, J.: A test of the optimality approach to modelling canopy properties and $\mathrm{CO}(2)$ uptake by natural vegetation, Plant Cell Environ., 30, 1586-1598, https://doi.org/10.1111/j.13653040.2007.01728.x, 2007.

Schymanski, S. J., Sivapalan, M., Roderick, M. L., Beringer, J., and Hutley, L. B.: An optimality-based model of the coupled soil moisture and root dynamics, Hydrol. Earth Syst. Sci., 12, 913932, https://doi.org/10.5194/hess-12-913-2008, 2008.

Schymanski, S. J., Sivapalan, M., Roderick, M. L., Hutley, L. B., and Beringer, J.: An optimality-based model of the dynamic feedbacks between natural vegetation and the water balance, Water Resour. Res., 45, 1412 , https://doi.org/10.1029/2008WR006841, 2009.

Schymanski, S. J., Roderick, M. L., and Sivapalan, M.: Using an optimality model to understand medium- and longterm responses of vegetation water use to elevated atmospheric CO2 concentrations, AoB Plants, 7, plv060, https://doi.org/10.1093/aobpla/plv060, 2015.

Scott, K., Setterfield, S. A., Douglas, M. M., Parr, C. L., Schatz, J., and Andersen, A. N.: Does long-term fire exclusion in an Australian tropical savanna result in a biome shift? A test using the reintroduction of fire, Aust. Ecol., 37, 693-711, https://doi.org/10.1111/j.1442-9993.2012.02379.x, 2012. 
Simioni, G., Roux, X. Le, Gignoux, J., and Sinoquet, H.: Treegrass: a $3 \mathrm{D}$, process-based model for simulating plant interactions in tree-grass ecosystems, Ecol. Modell., 131, 47-63, 2000.

Singh, J., Hanxi, Y., and Sajise, P.: Structural and functional aspects of Indian and southeast Asian savanna ecosystems., in International Savanna Symposium 1984, edited by: Tothill, J. and Mott, J., Australian Academy of Science, Canberra, 34-51, 1985.

Smith, B., Prentice, I. C., and Sykes, M. T.: Representation of vegetation dynamics in the modelling of terrestrial ecosystems: Comparing two contrasting approaches within European climate space, Glob. Ecol. Biogeogr., 10, 621-637, https://doi.org/10.1046/j.1466-822X.2001.t01-1-00256.x, 2001.

Sonnentag, O., Hufkens, K., Teshera-Sterne, C., Young, A. M., Friedl, M., Braswell, B. H., Milliman, T., O'Keefe, J., and Richardson, A. D.: Digital repeat photography for phenological research in forest ecosystems, Agr. Forest Meteorol., 152, 159177, https://doi.org/10.1016/j.agrformet.2011.09.009, 2012.

Steudle, E.: Water uptake by plant roots: an integration of views, Plant Soil, 226, 45-56, https://doi.org/10.1023/A:1026439226716, 2000.

Stevens, N., Lehmann, C. E. R., Murphy, B. P., and Durigan, G.: Savanna woody encroachment is widespread across three continents, Glob. Change Biol., 23, 235-244, https://doi.org/10.1111/gcb.13409, 2017.

Torello-Raventos, M., Feldpausch, T. R., Veenendaal, E., Schrodt, F., Saiz, G., Domingues, T. F., Djagbletey, G., Ford, A., Kemp, J., Marimon, B. S., Hur Marimon Junior, B., Lenza, E., Ratter, J. A., Maracahipes, L., Sasaki, D., Sonké, B., Zapfack, L., Taedoumg, H., Villarroel, D., Schwarz, M., Quesada, C. A., Yoko Ishida, F., Nardoto, G. B., Affum-Baffoe, K., Arroyo, L., M. J. S. Bowman, D., Compaore, H., Davies, K., Diallo, A., Fyllas, N. M., Gilpin, M., Hien, F., Johnson, M., Killeen, T. J., Metcalfe, D., Miranda, H. S., Steininger, M., Thomson, J., Sykora, K., Mougin, E., Hiernaux, P., Bird, M. I., Grace, J., Lewis, S. L., Phillips, O. L., and Lloyd, J.: On the delineation of tropical vegetation types with an emphasis on forest/savanna transitions, Plant Ecol. Divers., 6, 101-137, https://doi.org/10.1080/17550874.2012.762812, 2013.

Vrugt, J. A., van Wijk, M. T., Hopmans, J. W., and Šimunek, J.: One-, two-, and three-dimensional root water uptake functions for transient modeling, Water Resour. Res., 37, 2457-2470, https://doi.org/10.1029/2000WR000027, 2001.

Walter, H.: Vegetation of the earth in relation to climate and the eco-physiological conditions, English Universities Press, 1973.

Walter, H. and Burnett, J. H.: Ecology of tropical and subtropical vegetation, Oliver \& Boyd, 1971.

Wang, Y. P., Kowalczyk, E., Leuning, R., Abramowitz, G., Raupach, M. R., Pak, B., van Gorsel, E., and Luhar, A.: Diagnosing errors in a land surface model (CABLE) in the time and frequency domains, J. Geophys. Res., 116, G01034, https://doi.org/10.1029/2010JG001385, 2011.
Van Der Werf, G. R., Randerson, J. T., Giglio, L., Gobron, N., and Dolman, A. J.: Climate controls on the variability of fires in the tropics and subtropics, Global Biogeochem. Cy., 22, 1-13, https://doi.org/10.1029/2007GB003122, 2008.

Whitley, R., Beringer, J., Hutley, L. B., Abramowitz, G., De Kauwe, M. G., Duursma, R., Evans, B., Haverd, V., Li, L., Ryu, Y., Smith, B., Wang, Y.-P., Williams, M., and Yu, Q.: A model inter-comparison study to examine limiting factors in modelling Australian tropical savannas, Biogeosciences, 13, 3245-3265, https://doi.org/10.5194/bg-13-3245-2016, 2016.

Whitley, R. J., Macinnis-Ng, C. M. O., Hutley, L. B., Beringer, J., Zeppel, M., Williams, M., Taylor, D., and Eamus, D.: Is productivity of mesic savannas light limited or water limited? Results of a simulation study, Glob. Change Biol., 17, 3130-3149, https://doi.org/10.1111/j.1365-2486.2011.02425.x, 2011.

Williams, C. A., Hanan, N., Scholes, R. J., and Kutsch, W.: Complexity in water and carbon dioxide fluxes following rain pulses in an African savanna, Oecologia, 161, 469-480, https://doi.org/10.1007/s00442-009-1405-y, 2009.

Williams, M., Rastetter, E. B., Fernandes, D. N., Goulden, M. L., Wofsy, S. C., Shaver, G. R., Melillo, J. M., Munger, J. W., Fan, S.-M., and Nadelhoffer, K. J.: Modelling the soil-plantatmosphere continuum in a Quercus Acer stand at Harvard Forest: the regulation of stomatal conductance by light, nitrogen and soil/plant hydraulic properties, Plant Cell Environ., 19, 911-927, 1996.

Williams, M., Bond, B. J., and Ryan, M. G.: Evaluating different soil and plant hydraulic constraints on tree function using a model and sap flow data from ponderosa pine, Plant Cell Environ., 24, 679-690, https://doi.org/10.1046/j.13653040.2001.00715.x, 2001.

Yang, Q., HongLang, X., LiangJu, Z., MaoXian, Z., CaiZhi, L., and ShengKui, C.: Stable isotope techniques in plant water sources: a review, Arid Reg., 2, 112-122, 2010.

Zeppel, M., Macinnis-Ng, C., Palmer, A., Taylor, D., Whitley, R., Fuentes, S., Yunusa, I., Williams, M., and Eamus, D.: An analysis of the sensitivity of sap flux to soil and plant variables assessed for an Australian woodland using a soil-plant-atmosphere model, Funct. Plant Biol., 35, 509-520, https://doi.org/10.1071/FP08114, 2008. 